\title{
Effect of expansion of human umbilical cord blood CD34 + cells on neurotrophic and angiogenic factor expression and function
}

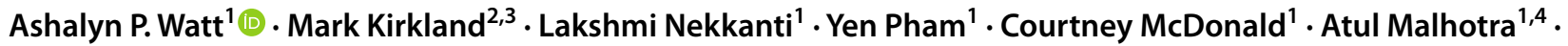 \\ Guy Moeneclaey ${ }^{1,2}$. Suzanne L. Miller ${ }^{1,5}$. Graham Jenkin ${ }^{1,5}$
}

Received: 1 June 2021 / Accepted: 19 January 2022 / Published online: 2 February 2022

(c) The Author(s) 2022

\begin{abstract}
The use of CD34 + cell-based therapies has largely been focused on haematological conditions. However, there is increasing evidence that umbilical cord blood (UCB) CD34 +-derived cells have neuroregenerative properties. Due to low cell numbers of CD34 + cells present in UCB, expansion is required to produce sufficient cells for therapeutic purposes, especially in adults or when frequent applications are required. However, it is not known whether expansion of CD34 + cells has an impact on their function and neuroregenerative capacity. We addressed this knowledge gap in this study, via expansion of UCB-derived CD34 + cells using combinations of LDL, UM171 and SR-1 to yield large numbers of cells and then tested their functionality. CD34 + cells expanded for 14 days in media containing UM171 and SR-1 resulted in over 1000-fold expansion. The expanded cells showed an up-regulation of the neurotrophic factor genes BDNF, GDNF, NTF-3 and NTF-4, as well as the angiogenic factors VEGF and ANG. In vitro functionality testing showed that these expanded cells promoted angiogenesis and, in brain glial cells, promoted cell proliferation and reduced production of reactive oxygen species (ROS) during oxidative stress. Collectively, this study showed that our 14-day expansion protocol provided a robust expansion that could produce enough cells for therapeutic purposes. These expanded cells, when tested in in vitro, maintained functionality as demonstrated through promotion of cell proliferation, attenuation of ROS production caused by oxidative stress and promotion of angiogenesis.
\end{abstract}

Keywords CD34 $\cdot$ Haematopoietic stem cells $\cdot$ Cell expansion $\cdot$ Neurotrophins $\cdot$ Angiogenesis

\section{Introduction}

Umbilical cord blood (UCB) contains a mixed population of stem and progenitor cells that includes haematopoietic stem cells (HSCs), endothelial progenitor cells (EPCs) and mesenchymal stromal cells (MSCs) (Phuc et al. 2012; Roura

Ashalyn P. Watt

ashalyn.watt@monash.edu

1 The Ritchie Centre, Hudson Institute of Medical Research, Clayton, VIC, Australia

2 Cell Care Australia, Heatherton, VIC, Australia

3 Institute for Frontier Materials, Deakin University, Waurn Ponds, Victoria, Australia

4 Department of Paediatrics, Monash University, Clayton, VIC, Australia

5 Department of Obstetrics and Gynaecology, Monash University, Clayton, VIC, Australia et al. 2015), together with immunosuppressive cells such as myeloid-derived suppressor cells (MDSC) and regulatory T cells (Tregs) (Tolar et al. 2009; Gervassi et al. 2014). This range of cell populations possess a diverse mix of multi-functional capacities to mediate tissue regeneration and repair, and combined with the straightforward nature of cord blood collection, makes UCB-derived cells a strong option for cell-based therapies. HSCs are commonly identified by their expression of the cell surface protein CD34, and HSCs make up between 0.5 to $1 \%$ of the total mononuclear cells (MNCs) population in cord blood collected at term birth (Kinniburgh and Russell 1993; Sutherland et al. 1994; Van Epps et al. 1994; Krause et al. 1996). UCB-HSCs are more primitive and have a lower risk of rejection compared to HSCs obtained from bone marrow, even when considering allogeneic use. This is because UCB-HSCs have low levels of HLA antigens which are critical in the mediation of graft-versus-host disease (Rocha et al. 2000; Tse et al. 2008; Park and Won 2009). Importantly, the concentration 
of CD34 + cells is tenfold greater in human cord blood when compared to peripheral blood (Murohara et al. 2000). In light of this, it is not surprising that UCB transplants are now being utilised in clinical settings for the treatment of a wide range of haematological and non-haematological diseases (Gluckman et al. 1989; Bradstock et al. 2006; Hügle and Daikeler 2010; Sebrango et al. 2010; Thompson et al. 2012; Shenoy 2013; Swart et al. 2017).

UCB-derived MNCs and UCB-derived HSCs are currently under clinical investigation for a wide range of regenerative medicine applications, with $>70$ clinical trials currently registered globally (Clinicaltrials.gov). Many of these regenerative or reparative trials are based around the therapeutic application for MNCs or HSCs to mediate neuropathology, across a spectrum of adult, childhood and neonatal conditions. These trials are predominantly centred around the capability of UCB-derived cells, including CD34 + haematopoietic stem cells and their progeny, to upregulate neurotrophic factors. A study by Paczkowska et al. assessed cord blood CD34+cells for expression of neurotrophic factors and showed that these CD34 + cells express brain-derived neurotrophic factor (BDNF), neurotrophin-3 (NTF-3), neurotrophin-4 (NTF-4), nerve growth factor (NGF) and glial-derived neurotrophic factor (GDNF). These cells also express the neurotrophic receptors; neurotrophic receptor tyrosine kinase 1 (TrkA), neurotrophic receptor tyrosine kinase 2 (TrkB), neurotrophic receptor tyrosine kinase 3 (TrkC) and nerve growth factor receptor (p75NTR) (Paczkowska et al. 2013). Aside from their engraftment potential and an established ability to restore the immunological system, HSCs secrete a range of proteins that regulate apoptosis and promote proliferation and repair, including cytokines, chemokines, anti-inflammatory factors and vascular growth factors (Aguila et al. 1997; Majka et al. 2001; Shizuru et al. 2005; Baraniak and McDevitt 2010; Czechowicz and Weissman 2011).

The majority of studies undertaken to characterise the neuroprotective or neuroreparative potential of HSCs have been performed in adult models of stroke and/or ischemia (Taguchi et al. 2004; Boltze et al. 2005; Shyu et al. 2006; Schäbitz et al. 2007; Schwarting et al. 2008; Felfly et al. 2010). The neuro-modulatory mechanisms of action of HSCs are also of interest as a treatment for neonatal brain injury, given that neonatal encephalopathy is often mediated via hypoxic ischemic injury that might benefit from the potential angiogenic and neurogenic properties exhibited by HSCs. In studies undertaken by our group, we have demonstrated that UCB provides neuroprotection in a neonatal hypoxic ischemic model (McDonald et al. 2018). In other studies, the administration of cord blood-derived CD34 + cells following neonatal hypoxic ischemic brain injury in mice and rats demonstrates that cell treatment may be protective, noting improved cerebral blood flow, a reduction in apoptosis, vascular regeneration and improved motor function (Ohshima et al. 2016; Yu et al. 2019). These data collectively suggest that HSCs have excellent neuroprotective potential for the immature brain; however, this is conditional on sufficient numbers of functional CD34 + cells being obtained.

Although umbilical cord blood is a rich source of HSCs compared to bone marrow and peripheral blood, the number of HSCs obtained from one cord blood sample at term birth may not be sufficient for therapeutic use in regenerative medicine applications, especially in adults and/or where multiple administrations are indicated (Qiu et al. 2021). In preclinical studies of neonatal brain injury, multiple doses of UCB-MNCs are more effective than a single dose of cells in reducing long-term neuroinflammation, cerebral tissue damage, and in improving behavioural outcomes (Penny et al. 2020). This highlights the need to develop methodologies to produce large numbers of functional UCB-derived cells, thus requiring a robust cell expansion protocol. Accordingly, in the current study we set out to optimise an expansion technique for CD34 + HSCs derived from pooled UCB CD34 + HSCs, to maximise the number of functional CD34 + cells obtainable. There has been considerable effort placed in identifying factors for use in the ex vivo expansion of CD34 + cells to promote proliferation and self-renewal. This includes the use of growth factors, inhibitors and small molecules (as reviewed by (Flores-Guzmán et al. 2013; Xie and Zhang 2015; Zhang and Gao 2016)); the addition of cytokines including, interleukin 6 (IL-6), stem cell factor (SCF), thrombopoietin (TPO), interleukin 3 (IL-3) and FMS-like tyrosine kinase 3 (FLT-3) and to the culture media (Petzer et al. 1996); and modulating oxygen levels under culture conditions (Tiwari et al. 2018). More recently, attention has turned to the use of small molecules to modulate stem cell fate, with StemRegenin-1 (SR-1) inclusion to TPO, IL-6, FLT-3 and SCF-containing media shown to induce a 50-fold increase in the number of HSCs obtained (Boitano et al. 2010). Furthermore, UM171 added to SCF, FLT-3, TPO and low-density lipoprotein (LDL) containing media has been shown to enable expansion of HSCs by up to 100-fold over 7 days of culture (Fares et al. 2014). Thus, the addition of these small molecules has led to progress in the clinical application of small molecule expanded HSCs for haematological uses (Wagner et al. 2016; Cohen et al. 2020; Dumont-Lagacé et al. 2020). It is, however, unknown if the addition of small molecules used during ex vivo expansion affects the production and expression of angiogenic and neurotrophic factors which, in turn, could impact the efficacy of expanded HSCs in neuroregenerative medicine. We hypothesised that UCB-derived CD34 + cell expansion using our protocol would not affect neurotrophic and angiogenic factor gene expression and that expanded CD34+ HSCs would retain their functional 
ability to promote proliferation and their neurotrophic and angiogenic activity.

\section{Materials and Methods}

\section{Ethics}

We obtained human ethics approval from Monash Health Human Ethics Committee, Monash Medical Centre for umbilical cord blood collection from term pregnancies (HREC Ref. Research Project No.: 12387B). The experiments that involved use of animals had ethics approval from Monash Medical Centre Animal Ethics Committee A (MMCA/2015/42). All experiments followed Australian National Health and Medical Research Council guidelines.

\section{Umbilical cord blood collection and isolation of cord blood CD34 + cells}

Human umbilical cord blood samples were obtained from women with uncomplicated pregnancies giving birth at term via elective caesarean section ( $>37$ weeks gestation), with all women providing written informed consent. After clamping of the cord and delivery of the placenta, UCB was collected from the umbilical vein using blood collection bags that contained anticoagulant (Macopharma). We obtained an average of approximately $80 \mathrm{ml}$ of UCB. To obtain the mononuclear fraction of cells, UCB was diluted 1:1 with PBS/2 mM EDTA and layered onto 50-ml Sepmate tubes (Stem Cell Technologies) that contained $13 \mathrm{ml}$ Ficoll-Paque Plus (GE Healthcare) and this was centrifuged at $1200 \mathrm{~g}$ for $15 \mathrm{~min}$. MNCs were washed twice with PBS/2 mM EDTA and centrifuged at $200 \mathrm{~g}$ for $10 \mathrm{~min}$ to produce a cell pellet that was collected in a 50-ml centrifuge tube. We used the trypan blue exclusion dye (Gibco) to assess cell viability, and cell number was quantified using a haemocytometer. The MNCs were then used for positive CD34 selection using a MACS bead separation system (Miltenyi Biotec), with all procedures performed according to manufacturer's instructions. Following isolation, CD34 + purity was quantified via flow cytometry and the isolates used were confirmed to have greater than $90 \%$ purity. Isolated UCB CD34 + cells were cryopreserved at a density of $1 \times 10^{6}$ cells $/ \mathrm{ml}$ in recovery cell culture freezing medium (Gibco) and stored in a vapour phase liquid nitrogen until required.

\section{Expansion of CD34 + cells}

CD34 + cells from up to 10 umbilical cord blood samples were thawed and pooled for expansion studies. The pooled CD34 cells were cultured in serum-free Stemspan Animal
Component-Free (ACF) media (Stem Cell Technologies) supplemented with $1 \%$ antibiotic/antimycotic (Life Technologies) and standard growth factors (SGF) consisting of $50 \mathrm{ng} / \mathrm{ml} \mathrm{SCF}, 50 \mathrm{ng} / \mathrm{ml} \mathrm{TPO}, 80 \mathrm{ng} / \mathrm{ml} \mathrm{FLT}-3$ and $100 \mathrm{ng} /$ $\mathrm{ml}$ IL-6 (Miltenyi Biotec). Combinations of the following were added to the SGF media; $20 \mu \mathrm{g} / \mathrm{ml} \mathrm{LDL}, 750 \mathrm{nM}$ SR-1 (Boitano et al. 2010) and UM171 (Stem Cell Technologies) at doses ranging from 35 to $400 \mathrm{nM}$. CD34 + cells were seeded in triplicate in 24-well tissue culture-treated plates (Corning) at $1 \times 10^{4}$ cells/well/1 $\mathrm{ml}$ and cultured in a dynamic setting by placing the plates on an orbital shaker at $20 \mathrm{rpm}$ in a $37^{\circ} \mathrm{C}$ incubator with $5 \% \mathrm{CO}_{2}$ and $5 \% \mathrm{O}_{2}$. The cells were cultured over 7 days with a media top-up on day 5 , before either being harvested at day 7 for analysis or split at a ratio of 1:20 and cultured for a further 7 days in the above media.

\section{Colony-forming unit (CFU) assays}

Colony-forming unit (CFU) assay was carried out for preand post-expanded cells using complete Methocult media (Stem Cell Technologies) following the manufacturer's instructions. The cells were resuspended in Methocult and seeded in triplicate onto $35 \mathrm{~mm}$ non-tissue culture-treated dishes at 1,000 cells $/ \mathrm{mL}$ and cultured at $37^{\circ} \mathrm{C}$ with $5 \% \mathrm{CO} 2$ for 14 days. The colonies were then manually counted using a light microscope (Olympus) to identify the burst-forming unit erythroid (BFU-E), colony-forming unit granulocyte, macrophage (CFU-GM), colony-forming unit granulocyte (CFU-G), colony-forming unit macrophage (CFU-M) and colony-forming unit granulocyte, erythrocyte, macrophage, megakaryocyte (CFU-GEMM) cells.

\section{Flow cytometry}

\section{Phenotypic analysis}

After 7 and 14 days of culture, the expanded cells were analysed for CD34 purity. Flow cytometric analysis for surface markers was performed using the following antibodies: CD34 PE, CD45 APC, 7AAD, CD133 BV421, CD43 BV510 and CD90 PE-CY7 (all antibodies from BD Biosciences). Single stains were used for compensation and fluorescence minus one (FMO) was used for setting gates. Antibody-stained cells were assessed using a FACS Canto II (BD Biosciences) flow cytometer, using FACSDiva software (BD Biosciences). Mean and standard error values were determined from at least three independent experiments, with each experiment performed in triplicate. Fold expansion of CD34 + and other lineage-specific cells after 7 and 14 days of culture was calculated by comparing the proportion of cells, compared to the initial seeding of $1 \times 10^{4}$ cells. 


\section{Cell cycle analysis}

Cell cycle analysis was conducted using 7AAD staining. Cells were first fixed by adding ice cold $80 \%$ ethanol via a dropper and then incubated for $2 \mathrm{~h}$ at $-20{ }^{\circ} \mathrm{C}$. Fixed cells were washed three times with FACS buffer $(2 \%$ FBS in $1 \times$ PBS) treated with RNase and stained with 7AAD for $30 \mathrm{~min}$. Cells were analysed in an FACS Canto II (BD Biosciences) flow cytometer using FACSDiva software.

\section{Tube formation assay}

Human umbilical vein endothelial cells (HUVECs) (Life Technologies) were cultured in medium 200 with $1 \times$ LVES supplement (Life Technologies). For the tube formation assay, $200 \mu \mathrm{l}$ of thawed geltrex (growth factor reduced) was added to the bottom of a 24 well plate and allowed to set for $1 \mathrm{~h}$ in a $37^{\circ} \mathrm{C}$ incubator. HUVECs $\left(2 \times 10^{4}\right)$ were plated in medium 200 basal media with no supplements and $2 \times 10^{5}$ CD34 + cells placed in a transwell $(0.4 \mu \mathrm{M}$ pore $)$ above the culture and incubated for $24 \mathrm{~h}$. Images were taken on an Olympus CX53 microscope analysed using the Image $\mathbf{J}$ angiogenesis tool.

\section{Glial cell proliferation assay}

A population of mixed glial cells were isolated from the cortex of 3-day old rat pup brains. At post-mortem, brains were dissected and cortical tissue separated and digested using a neural tissue dissociation kit (P) (Miltenyi Biotec), following manufacturer's specifications. Single cells were plated on poly-l-ornithine coated flasks in growth media containing DMEM, $2 \times$ B27 supplement and $1 \times$ antibiotic/ antimycotic in a $37^{\circ} \mathrm{C}$ incubator with $5 \% \mathrm{CO}_{2}$. After one week in culture, the cells were dissociated with accutase solution (Life Technologies) and plated in 24 well plates pre-coated with poly-l-ornithine at a density of $5 \times 10^{3}$ cells per well in media containing DMEM and $1 \times$ B27 supplement. Expanded CD34+ cells were placed above the cells in a transwell polycarbonate insert with a $0.4 \mu \mathrm{M}$ pore at a density of $1 \times 10^{5}$ cells. Proliferation of the glial cells was measured using the CyQuant cell proliferation assay (Life Technologies) following the manufacturer's specifications.

\section{Oxidative stress and ROS production}

To assess ROS production induced by oxidative stress in the mixed glial cells, a DCFDA kit (Abcam) was used following manufacturer's specifications. Glial cells were stained for 30 min with $20 \mu \mathrm{M}$ DCFDA, and then tert-butyl hydroperoxide (TBHP) was added at a concentration of $5 \mu \mathrm{M}$ to induce oxidative stress (Roy and Sil 2012) with/without the addition of pre- or post-expanded CD34 + cells placed in a transwell for $24 \mathrm{~h}$. Fluorescence was measured using a microplate reader with an ex/em 485/535 nm.

\section{Microglia anti-inflammatory assay}

Microglia were isolated from $\mathrm{P} 3$ rat pup brain cortices using MACS bead separation for positive selection of CD11b (Miltenyi Biotec). Once isolated, microglia were cultured in poly-D-lysine coated tissue culture flasks in serum free conditions of 50\% DMEM/50\% Neurobasal media, $1 \% \mathrm{~N} 2$ supplement, $1 \%$ antibiotic/antimycotic (all from Life Technologies). Once the cells reached $80 \%$ confluence, they were plated in 24 well plates $\left(4 \times 10^{4}\right.$ cells/well $\left./ 0.5 \mathrm{ml}\right)$ and challenged with $100 \mathrm{ng} / \mathrm{ml}$ lipopolysaccharide (LPS) from Escherichia coli O111:B4 (Sigma Aldrich) with/without the addition of $2 \times 10^{5} \mathrm{CD} 34+$ cells, placed in a transwell $(0.4 \mu \mathrm{M}$ pore $)$ above the culture. After $24 \mathrm{~h}$, RNA was extracted from the microglial cells for gene expression analysis.

\section{RNA extraction and cDNA synthesis}

RNA was extracted from pooled CD34+ cells pre- and postexpansion ( $\mathrm{n}=9$ pooled donors) using a PureLink RNA extraction kit following the manufacturer's instructions, including the optional on-column DNase treatment using PureLink DNase set (Life Technologies). cDNA was synthesised from RNA extracted from CD34 + cells following the iScript reverse transcriptase protocol (Bio-Rad). RNA and cDNA concentrations were measured using a nanodrop spectrophotometer (Thermo Fisher) and stored at $-80{ }^{\circ} \mathrm{C}$ or $-20{ }^{\circ} \mathrm{C}$, respectively, until required.

\section{Gene expression analysis}

qPCR was conducted on cDNA from pre- and post-expanded CD34 + cells and was used to identify the expression of neurotrophic and angiogenic-related genes. Gene specific primers.

were designed (Table 1) using glyceraldehyde-3-phosphate dehydrogenase (GAPDH) and/or beta-2 macroglobulin (B2M) as the housekeeping gene for normalisation. PCRs were carried out using the Quant studio 6 Flex Real-Time PCR system (Applied Biosystems). Ten microlitres of reaction mixtures contain $5 \mu \mathrm{l} \mathrm{SYBR}$ Green PCR master mix (Applied Biosystems), $50 \mathrm{ng}$ cDNA and $250 \mathrm{nM}$ forward and reverse primers. The relative gene expression was determined using the comparative $\mathrm{Ct}$ method.

\section{Statistics}

Statistical analysis was carried out using GraphPad Prism software, and all data are presented as mean \pm standard error 
Table 1 Primer list

\begin{tabular}{lll}
\hline Primer name & Sequence & Product size \\
\hline Hu-GAPDH-fwd & AGAAGGCTGGGGCTCATTTG & 82 \\
Hu-GAPDH-rev & ATGACGAACATGGGGGCATC & \\
Hu-B2M-fwd & GGGTTTCATCCATCCGACA & 218 \\
Hu-B2M-rev & GCTTACATGTCTCGATCCCAC & \\
Hu-ANGPT1-fwd & TGGGGGAGGTTGGACTGTAA & 149 \\
Hu-ANGPT1-rev & GCCTCTGACTGGTAATGGCA & \\
Hu-ANG-fwd & TTCTGCGGACTTGTTCTGAG & 148 \\
Hu-ANG-rev & GTCAGGAAGTGTGTGTACCTG & \\
Hu-NTF3-fwd & GGTACGCGGAGCATAAGAGTC & 141 \\
Hu-NTF3-rev & GAGAGTTGCCCGTTTTGATCT & \\
Hu-NTF4-fwd & GCGAGGTGGAGGTGTTGG & 100 \\
Hu-NTF4-rev & CCTTCCTCAGCGTTATCAGC & \\
Hu-VEGFA-fwd & TGCAGATTATGCGGATCA & 81 \\
& AACC & \\
Hu-VEGFA-rev & TGCATTCACATTTGTTGTGCT & \\
& GTAG & \\
Hu-GDNF-fwd & TGACTTGGGTCTGGGCTATG & 174 \\
Hu-GDNF-rev & TCATCAAAGGCGATGGGTCT & \\
Hu-BDNF-fwd & GATGCTCAGTAGTCAAGTGCC & 168 \\
Hu-BDNF-rev & GCCGTTACCCACTCACTA & \\
& ATAC & \\
\hline
\end{tabular}

of the mean. Analysis of CD34+expansion, glial cell proliferation, tube formation assays and gene expression analysis were conducted using a one-way ANOVA and where appropriate a two-way ANOVA, both with a Tukey post hoc test. Significance was annotated as $\mathrm{P}<0.05 *, \mathrm{P}<0.01 * *$ and $\mathrm{P}<0.001 * * *$ or no significance ns.

\section{Results}

\section{CD34 + 7 versus 14 day expansion}

Firstly, we compared our standard 7-day expansion versus a 14-day expansion with a 1:20 split at day 7, using media containing standard growth factors (SGF) (TPO, SCF, IL-6 and FLT-3) or in addition, a combination of the following molecules: UM171 (35 nM), SR-1 (750 nM) and LDL $(20 \mu \mathrm{g} / \mathrm{ml})$. At 7 days of expansion, the CD34+ cells were assessed for CD34/CD45 expression (Table 2). After 7 days of expansion, the highest fold expansion of CD34+/ CD $45+$ cells was observed in the group containing both UM171 and LDL $(45.1 \pm 1.6)$; however, the percentage of cells expressing CD34/CD45 was highest in the group containing UM171 and SR-1 $(68.1 \pm 2.7)$. This indicates that the combination containing LDL promoted more proliferation but caused further maturation of the cells.

At day 7, the cells were split at a 1:20 ratio and cultured for a further 7 days to increase cell yield. At 14 days, the cell cultures were assessed for total cell counts, CD34+/ CD45 + positivity, and total CD34 + /CD45 + fold expansion. After 14 days of culture, all groups had significantly higher total cell counts and CD34+/CD45 + fold expansion compared to day 7; however, all groups had significantly lower CD34 +/CD45 + positivity in the cultures compared to pre-expansion and day 7. After 14 days of expansion, the group containing UM171 and SR-1 resulted in the highest number of cells in the cell counts, as well as fold expansion $(532.0 \pm 73.3)$ and CD34 +/CD $45+$ expression $(42.3 \pm 2.7)$ compared to all other groups. As the addition
Table 2 Assessment of 7- and 14-day CD34 + expansion

\begin{tabular}{llclc}
\hline Condition & $\begin{array}{l}\text { Time of } \\
\text { culture (days) }\end{array}$ & Total cell counts $\left(\times 10^{6}\right)$ & $\begin{array}{l}\text { CD34+CD45 + cell } \\
\text { positivity }(\%)\end{array}$ & $\begin{array}{c}\text { Fold expansion } \\
\text { CD34+CD45+ }\end{array}$ \\
\hline SGF & 7 & $0.625 \pm 0.048$ & $27.9 \pm 3.3$ & $17.6 \pm 2.3$ \\
& 14 & $6.958 \pm 0.57^{*}$ & $20.0 \pm 1.9^{*}$ & $99.3 \pm 11.9^{*}$ \\
UM171 & 7 & $0.54 \pm 0.022$ & $56.7 \pm 3.0$ & $32.0 \pm 1.7$ \\
& 14 & $8.568 \pm 0.73^{*}$ & $35.2 \pm 1.3^{*}$ & $300.2 \pm 36.3^{*}$ \\
SR-1 & 7 & $0.644 \pm 0.021$ & $44.1 \pm 2.5$ & $28.8 \pm 1.5$ \\
& 14 & $8.627 \pm 0.92^{*}$ & $31.8 \pm 0.7^{*}$ & $244.2 \pm 31.3^{*}$ \\
LDL & 7 & $0.699 \pm 0.020$ & $32.7 \pm 2.8$ & $22.1 \pm 1.7$ \\
& 14 & $9.984 \pm 0.85^{*}$ & $23.8 \pm 1.1^{*}$ & $170.7 \pm 14.5 *$ \\
UM171 + SR-1 & 7 & $0.551 \pm 0.02$ & $68.1 \pm 2.7$ & $38.9 \pm 0.96$ \\
& 14 & $12.28 \pm 1.11^{*}$ & $42.3 \pm 2.7^{*} \#$ & $532.0 \pm 73.3^{*} \#$ \\
UM171 + LDL & 7 & $0.754 \pm 0.023$ & $57.6 \pm 2.6$ & $45.1 \pm 1.6$ \\
& 14 & $11.46 \pm 0.78^{*}$ & $35.5 \pm 1.8^{*}$ & $392.8 \pm 47.7^{*}$ \\
SR-1 + LDL & 7 & $0.801 \pm 0.048$ & $42.5 \pm 4.0$ & $32.6 \pm 1.8$ \\
& 14 & $11.558 \pm 1.02^{*}$ & $30.6 \pm 1.3^{*}$ & $289.1 \pm 37.3^{*}$ \\
\hline
\end{tabular}

$* \mathrm{P}<0.05$ compared to day 7

$* * \mathrm{P}<0.05 \mathrm{UM} 171+\mathrm{SR} 1$ compared to all other groups 
of $\mathrm{UM} 171+\mathrm{SR}-1$ resulted in the highest expansion rate, all further experiments were conducted using this combination.

\section{Effect of UM171 dose on CD34 + expansion}

To further assess the effect of UM171 concentration on CD34 + expansion, UM171 was added to SGF at the following concentrations: $50 \mathrm{nM}, 100 \mathrm{nM}, 150 \mathrm{nM}, 200 \mathrm{nM}$ and $400 \mathrm{nM}$, along with SR-1 at $750 \mathrm{nM}$ (Table 3). At day 7 , the highest fold expansion of CD34+/CD45+ cells was observed in the group containing $150 \mathrm{nM}$ UM171 $(75.3 \pm 5.8)$. However, the highest CD $34+/ C D 45+$ positivity was observed in the group containing 400 nM UM171 $(93.0 \% \pm 0.9)$, but this concentration also had a significantly lower fold expansion than all other groups (49.6 \pm 0.4$)$. By day 14 of expansion, all groups had significantly higher cell counts and an increase in fold expansion of CD34 +/ CD45 + cells when compared to day 7 of expansion. Two groups resulted in over 1000 fold expansion of CD34/ CD45 + cells after 14 days, these were UM171 at $100 \mathrm{nM}$ $(1167.3 \pm 89.6)$ and $150 \mathrm{nM}(1120.5 \pm 90.6)$. The highest CD34+/CD45 + cell purity post-expansion at 14 days was observed when UM171 was used at $400 \mathrm{nM}(87.7 \pm 0.7)$; however, at this dose there was a significant impact on cell proliferation, resulting in lower cell counts and a lower CD34 + /CD45 + fold expansion $(643.8 \pm 5.6)$. These results support that CD34+/CD45 + positivity after expansion increased with increasing UM171 concentrations. In contrast, fold expansion significantly declined as UM171 concentration increased at $200 \mathrm{nM}$ and above. Taken collectively, although UM171 at $100 \mathrm{nM}$ provided the highest fold expansion of CD34+/CD45 + cells, there was no significant difference between fold expansion of CD34 +/CD45 + cells between UM171 at $100 \mathrm{nM}$ and $150 \mathrm{nM}(\mathrm{P}=0.724)$. However, UM171 at the concentration of $150 \mathrm{nM}$ resulted in significantly higher CD34 +/CD45 + positivity compared
Table 4 Stem cell marker populations

\begin{tabular}{lccl}
\hline $\begin{array}{l}\text { Cell populations } \\
\text { (\% positivity) }\end{array}$ & Pre-expansion & $\begin{array}{l}\text { Day 14 } \\
\text { expanded in } \\
\text { SGF }\end{array}$ & $\begin{array}{l}\text { Day 14 expanded } \\
\text { in UM171+SR-1 }\end{array}$ \\
\hline CD34+CD45+ & $94.7 \pm 0.8$ & $20.0 \pm 1.9^{*}$ & $78.9 \pm 2.4^{* \#}$ \\
CD34+CD133+ & $52.8 \pm 3.2$ & $9.4 \pm 2.3^{*}$ & $48.5 \pm 2.7 \#$ \\
CD34+CD90+ & $13.0 \pm 2.5$ & $12.9 \pm 1.3$ & $55.9 \pm 2.4^{* \#}$ \\
CD34+CD45+ & $7.5 \pm 2.3$ & $6.6 \pm 0.9$ & $35.3 \pm 3.0^{* \#}$ \\
CD43+CD90 & & & \\
+ CD133+ & & & \\
\hline
\end{tabular}

$* \mathrm{P}<0.05$ compared to pre-expansion

$* * \mathrm{P}<0.05 \mathrm{UM} 171+\mathrm{SR} 1$ compared to SGF

to $\mathrm{UM} 171$ at $100 \mathrm{nM}(78.9 \%$ and $71.5 \%$, respectively, $\mathrm{P}=0.039$ ), so the concentration of UM171 at $150 \mathrm{nM}$ was used for all further experiments.

\section{Effect of 14-day CD34 + cell expansion on stem cell phenotype}

Phenotypical characterisation of the 14-day expanded CD34 + cells cultured in either SGF or with $150 \mathrm{nM}$ UM171 + and $750 \mathrm{nM}$ SR-1 was performed using flow cytometric analysis of CD34, CD45, CD133, CD90 and CD43 expression. Pre-expanded CD34 + were used with a minimum purity of $90 \%$ for CD34/CD $45+$ cells for all expansion experiments with an average of $94.7 \pm 0.8 \%$ (Table 4). After 14 days of expansion in SGF media, the CD34/CD45 + cells were $20.0 \pm 1.9 \%$, whereas addition of $\mathrm{UM} 171+\mathrm{SR}-1$ resulted in $78.9 \pm 2.4 \%$ CD34/CD $45+$ cells (Fig. 1a-c, Table 4). The CD34/CD133+ population, defined as both HSCs and endothelial progenitor cells (EPCs), showed that $52.8 \pm 3.2 \%$ of the cells co-expressed these two markers before expansion and, after 14 days of expansion in SGF, this was significantly reduced to
Table 3 Effect of UM171 dose on CD34+expansion at 7 and 14 days

\begin{tabular}{llclc}
\hline $\begin{array}{l}\text { UM171 } \\
\text { concentration } \\
(\mathrm{nM})\end{array}$ & $\begin{array}{l}\text { Time of } \\
\text { culture (days) }\end{array}$ & Total cell counts $\left(\times 10^{6}\right)$ & $\begin{array}{l}\text { CD34+CD45+cell } \\
\text { positivity }(\%)\end{array}$ & $\begin{array}{c}\text { Fold expansion } \\
\text { CD34+CD45+ }\end{array}$ \\
\hline $\mathbf{5 0}$ & 7 & $0.802 \pm 0.024$ & $77.8 \pm 0.8$ & $68.3 \pm 12.0$ \\
& 14 & $13.28 \pm 0.357^{*}$ & $52.5 \pm 1.7^{*}$ & $896.3 \pm 53.3^{*}$ \\
$\mathbf{1 0 0}$ & 7 & $0.7243 \pm 0.023$ & $86.4 \pm 0.7$ & $70.4 \pm 10.5$ \\
& 14 & $12.553 \pm 0.358^{*}$ & $71.5 \pm 1.0^{*}$ & $1167.3 \pm 89.6^{*}$ \\
$\mathbf{1 5 0}$ & 7 & $0.805 \pm 0.056$ & $89.1 \pm 1.2$ & $75.3 \pm 5.8$ \\
& 14 & $12.160 \pm 0.765^{*}$ & $78.9 \pm 2.4^{*}$ & $1120.5 \pm 90.6^{*}$ \\
$\mathbf{2 0 0}$ & 7 & $0.583 \pm 0.032$ & $91.4 \pm 1.1$ & $55.9 \pm 2.7$ \\
& 14 & $10.902 \pm 0.141^{*}$ & $81.3 \pm 0.5^{*}$ & $917.0 \pm 11.6^{*}$ \\
$\mathbf{4 0 0}$ & 7 & $0.506 \pm 0.05$ & $93.0 \pm 0.9$ & $49.6 \pm 0.4$ \\
& 14 & $7.201 \pm 0.042^{* *}$ & $87.7 \pm 0.7^{*}$ & $643.8 \pm 5.6^{*} \#$ \\
\hline
\end{tabular}

$* \mathrm{P}<0.05$ compared to day 7

** $\mathrm{P}<0.05$ comparing UM171 at $400 \mathrm{nM}$ to all other UM171 doses 


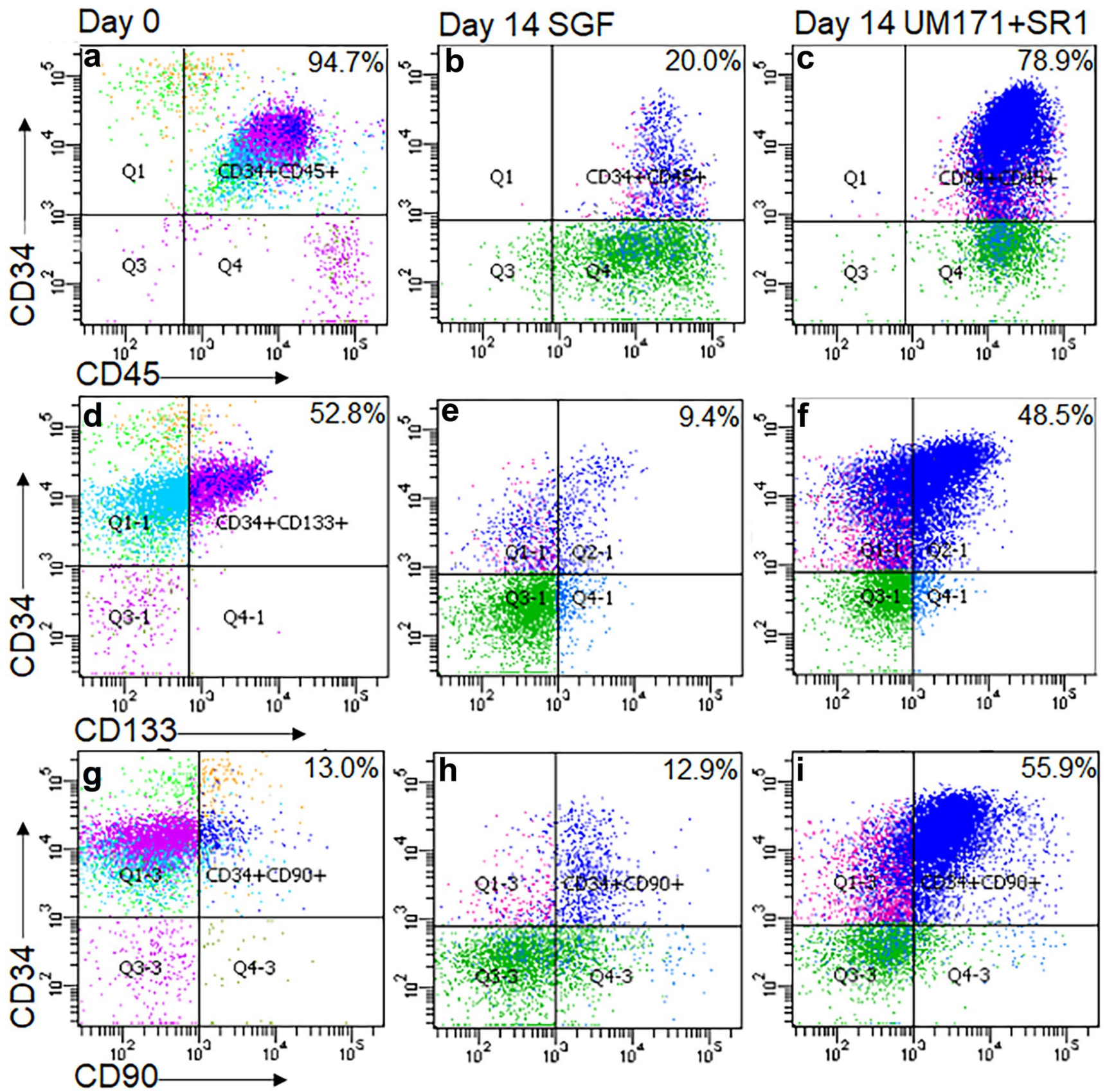

Fig. 1 Stem cell phenotype analysis. Flow cytometry analysis of CD34 + cells prior to expansion (day 0) and after 14 days of expansion in either SGF containing media or UM171 + SR1 containing media for

$9.4 \pm 2.3 \%$ and in UM171/SR-1 containing media to $48.5 \pm 2.7 \%$ (Fig. 1d-f, Table 4). The CD34/CD90+ population showed that $13.0 \pm 2.5 \%$ of the cells co-expressed these two markers before expansion and, after 14 days of expansion in SGF, similar positivity of $12.9 \pm 1.3 \%$ was observed and in UM171/SR-1 containing media significantly increased to $55.9 \pm 2.4 \%$ (Fig. $1 \mathrm{~g}-\mathrm{i}$, Table 4 ). co-expression of CD34/CD45 + (a-c), CD34/CD133+(d-f) and CD34/ $\mathrm{CD} 90+(\mathbf{g}-\mathbf{i})$ populations

Further analysis of cells expressing CD34/CD45/CD43/ CD133/CD90 + showed that, at day 0 pre-expansion, the proportion of the CD34/CD45/CD43/CD133/CD90+ cells was $7.5 \pm 2.3 \%, 6.6 \pm 0.9 \%$ at day 14 in SGF media and significantly increased to $35.3 \pm 3.0 \%$ in UM171 + SR-1 media (Table 4). 


\section{Effect of 14-day CD34 + cell expansion on cell cycle}

At 14 days, expansion in media containing SGF resulted in $54.8 \% \mathrm{G} 0 / \mathrm{G} 1,10.5 \% \mathrm{~S}$ and $10.3 \% \mathrm{G} 2 \mathrm{M}$ cells (Fig. 2a). At 14 days, with the addition of $150 \mathrm{nM}$ UM171 and $750 \mathrm{nM}$ $\mathrm{SR}-1,73.3 \%$ of cells were in the G0/G1 phase, $8.1 \% \mathrm{~S}$ and $13.3 \%$ G2M. When compared to pre-expansion CD34+ cells, there were significantly less cells in G0/G1 phase in both day-14 cells expanded in SGF media $(\mathrm{p}<0.001)$ and $\mathrm{UM} 171+\mathrm{SR}-1$ media $(\mathrm{p}<0.001)$, but significantly more cells in G0/G1 in day-14 cells expanded in UM171 + SR-1 $(\mathrm{p}<0.001)$ compared to those cultured in SGF media. For $\mathrm{S}$ phase, there were significantly more cells when expanded for

a

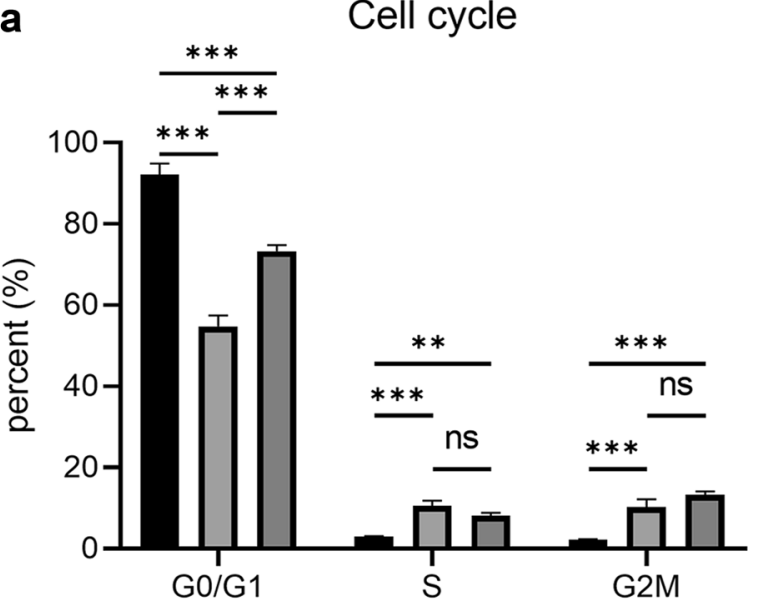

b

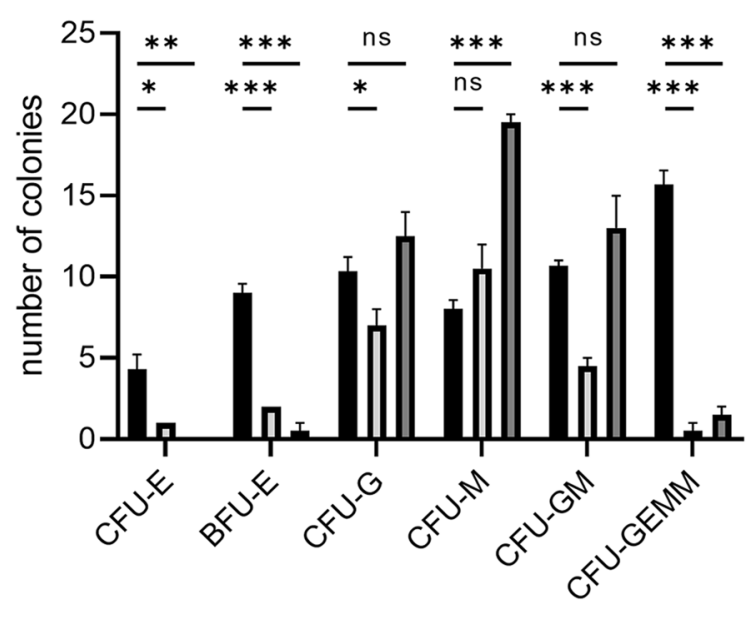

ש Day 0 Day 14 SGF ש Day 14 UM171/SR-1

Fig. 2 Cell cycle and colony-forming (CFU) unit assay. Flow cytometrybased cell cycle analysis of day 0 pre-expansion CD34+cells, Day 14 expanded CD34+cells in SGF media, Day 14 expanded CD34+cells in UM171 + SR-1 media (a). CFU assay for colony counting for CFUE, BFU-E, CFU-G, CFU-GM, CFU-GEMM (b). $* \mathrm{P}<0.05$, **P $<0.01$, $* * * \mathrm{P}<0.001, \mathrm{~N}=3$ independent experiments
14 days in both SGF media $(\mathrm{p}<0.001)$ and UM171 + SR-1 media $(p=0.003)$ compared to pre-expansion and no difference between expanded cells in SGF media compared to $\mathrm{UM} 171$ + SR-1 containing media $(\mathrm{p}=0.197)$. For G2M phase, there were significantly more cells when expanded for 14 days in both SGF media $(\mathrm{p}<0.001)$ and UM171 + SR-1 media ( $\mathrm{p}<0.001$ ) compared to CD34 + cells pre-expansion, but no significant difference in cells expanded for 14 days in SGF or UM171 + SR-1 ( $p=0.093)$.

\section{Effect of 14-day CD34 + cell expansion on colony-forming unit (CFU) assay}

To assess clonal capacity of the CD34 + cells after 14-day expansion, the colony-forming unit (CFU) assay was used (Fig. 2b). For CFU-E, there was a significantly reduced colony count when compared to day 0 pre-expanded CD34 + cells; an average of 4.3 colonies at Day $0,1.0$ colony at day 14 in SGF media $(p=0.018)$ and no colonies observed at day 14 in media containing UM171 + SR-1 $(\mathrm{p}=0.002)$. For BFU-E, the highest colony count was observed for pre-expansion, at 8.7 colonies, and a significant decline in colonies was observed for day 14 cells expanded in SGF media $(1.7$ colonies; $\mathrm{p}<0.001)$ and day 14 cells expanded in UM171 + SR-1 media (1.4 colonies; p $<0.001)$. For CFU-G colonies, day 0 pre-expansion contained 10.3 colonies where day 14 SGF expanded CD34 + cells were significantly down-regulated at 7.3 colonies $(p=0.018)$; however, the day 14 UM171 + SR-1 expanded CD34 + cells showed no significant difference with 12.5 colonies $(p=0.143)$. There was no significant difference in the number of CFU-G colonies across all groups. For CFU-M, there was no difference between pre-expanded CD34 + cells and after expansion in SGF media $(\mathrm{p}=0.083)$; however, expansion with UM171 + SR-1 significantly increased the number of CFU-M colonies compared to both pre-expansion and SGF expanded cells $(\mathrm{p}<0.001)$. CFU-GM pre-expanded CD34 + cells resulted in 10.7 colonies and a significant decline in colonies were observed for day 14 cells expanded in SGF media (4.5 colonies) $(\mathrm{p}<0.001)$; however, there was no significant difference between pre- and post-expanded CD34 + cells in UM171 + SR-1 media (12.6 colonies) $(p=0.109)$. For CFU-GEMM, the highest colony count was observed for pre-expansion at 15.7 colonies and a significant decline in colonies was observed for day 14 cells expanded in SGF media $(0.6$ colonies; $\mathrm{p}<0.001)$ and UM171 + SR-1 media $(1.5$ colonies; $\mathrm{p}<0.001)$.

\section{Effect of CD34 + cell expansion on neurotrophic and angiogenic factor gene expression}

Previous reports have shown that CD34+cells express neurotrophic and angiogenic factor genes (Paczkowska 
et al. 2016). RT-qPCR was used to determine if a 14-day expansion using UM171 and SR-1 affected neurotrophic and angiogenic factor gene expression. CD34 + expansion with UM171 and SR-1 showed a significant upregulation of GDNF ( $p<0.001)$, BDNF ( $<<0.001)$, NTF-3 ( $<<0.001)$ and NTF-4 ( $\mathrm{p}<0.001)$ (Fig. 3a), compared to pre-expanded $\mathrm{CD} 34+$ cells. For angiogenic factor gene expression, expanded $\mathrm{CD} 34+$ cells showed a significant up-regulation of ANG ( $\mathrm{p}<0.001)$ and VEGFA ( $\mathrm{p}<0.01)$ compared to preexpanded cells, but no significant difference was observed for ANGPT1 (Fig. 3b).

\section{a neurotrophic factor gene expression}

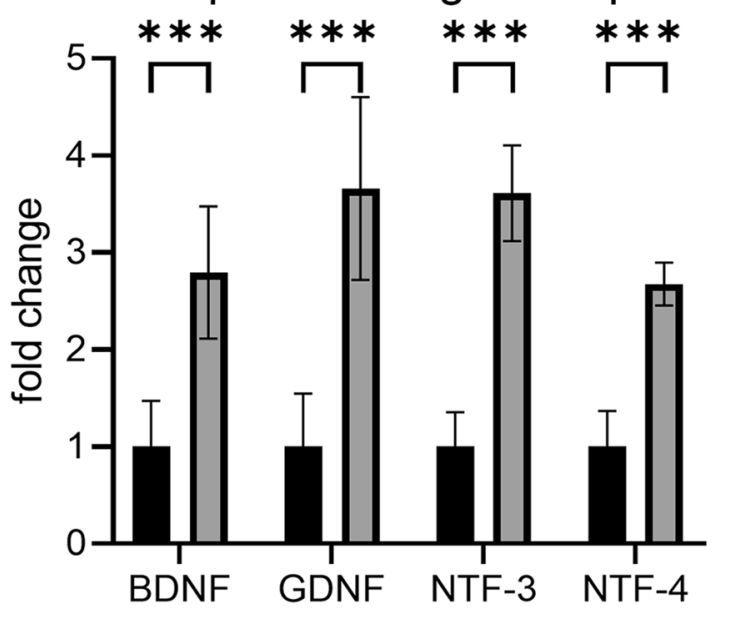

b angiogenic factor gene expression

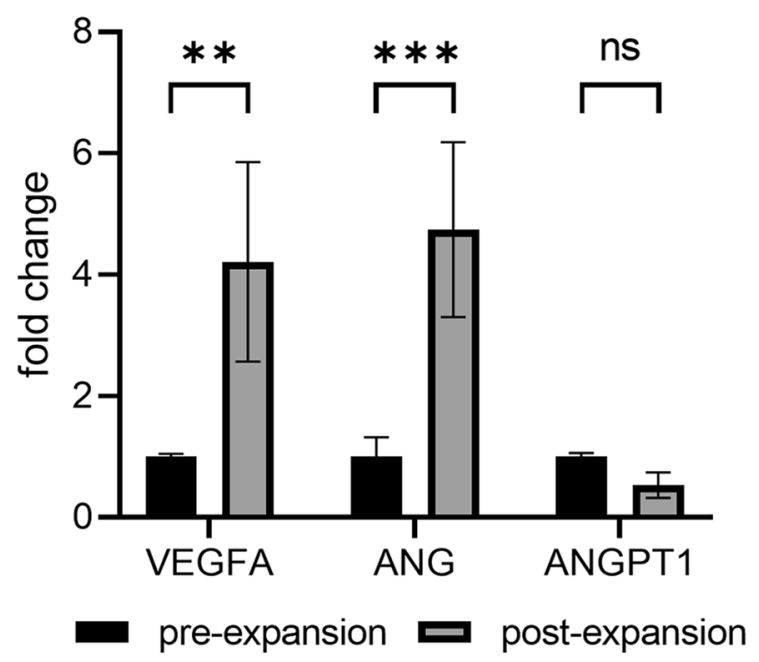

Fig. 3 Neurotrophic and angiogenic factor gene expression. Gene expression from pre- and post-expanded CD34+cells for neurotrophic factor gene expression for GDNF, BDNF, NTF-3 and NTF-4 (a). Angiogenic factor gene expression for VEGFA, ANG and ANGPT1 (b). Gene expression shown relative to GAPDH. $* * \mathrm{P}<0.01$, $* * * \mathrm{P}<0.001$ or $\mathrm{ns}-$ not significant, $\mathrm{N}=3$ independent experiments, performed in triplicate

\section{Expanded CD34 + cells promote tube formation in vitro}

To assess if 14-day expansion of CD34 + cells in the presence of UM171 + SR-1 retained their angiogenic potential, a tube formation assay was used (Fig. 4). Expanded CD34+cells showed a significant increase in the numbers of nodes ( $p=0.017$, Fig. 4a), junctions ( $p=0.0076$, Fig. $4 b)$, meshes $(p=0.032$, Fig. $4 c)$ and segments $(p=0.0038$, Fig. 4f) but not master junctions ( $p=0.068$, Fig. 4 e), compared to the untreated control. The addition of expanded CD34 + cells significantly decreased the number of HUVEC isolated segments $(p=0.017$, Fig. $4 \mathrm{~g})$, which are too small to form branches/segments. However, the expanded CD34 + cells significantly increased the total branching length $(p=0.0067)$ and the total segment length $(p=0.04)$ when compared to untreated control (Fig. $4 \mathrm{~d}$ and $\mathrm{h}$ ).

\section{Expanded CD34 + cells promote glial cell proliferation}

Mixed glial cells were isolated from the cortex of post-natal day 3 rat pups and used for proliferation assays. Pre- or post-expansion CD34+ cells were placed in $0.4 \mu \mathrm{M}$ transwells above the glial cell monolayer and cultured over two days. After 1 day, both the pre- and post-expanded $\mathrm{CD} 34+$ cells significantly promoted proliferation of the glial cells $(p=0.003$ and $p=0.004$, respectively $)$ and after 2 days of culture this was further increased with preexpanded CD34 + cells $(\mathrm{p}<0.001)$ and post-expanded $\mathrm{CD} 34+(\mathrm{p}<0.001)$ further increasing cell proliferation. The greatest increase in glial cell proliferation was observed in the post-expanded CD34 + group when compared to preexpanded CD34 + cells ( $p<0.001$, Fig. 5a).

\section{Expanded CD34 + cells can attenuate ROS production during oxidative stress}

Oxidative stress has a negative impact on cells in the brain, and reactive oxygen species (ROS) are generated in response to hypoxia ischemia. In this study, we tested the ability of CD34 + cells to provide anti-oxidant support to glial cells that had been exposed to $5 \mu \mathrm{M}$ tert-butyl hydroperoxide (TBHP) which causes oxidative stress (Roy and Sil 2012). There was a significant upregulation of ROS production in glial cells when exposed to TBHP $(p<0.001)$ compared to untreated cells (Fig. 5b). Treatment of the glial cells with TBHP along with non-expanded CD34+ cells or 14-day expanded CD34 + cells resulted in a significant down-regulation of ROS generation from the glial cells $(\mathrm{p}<0.001)$. There was no significant difference between non-expanded CD34 or expanded CD34 cells in their ability to attenuate $\operatorname{ROS}(\mathrm{p}=0.95)$. 


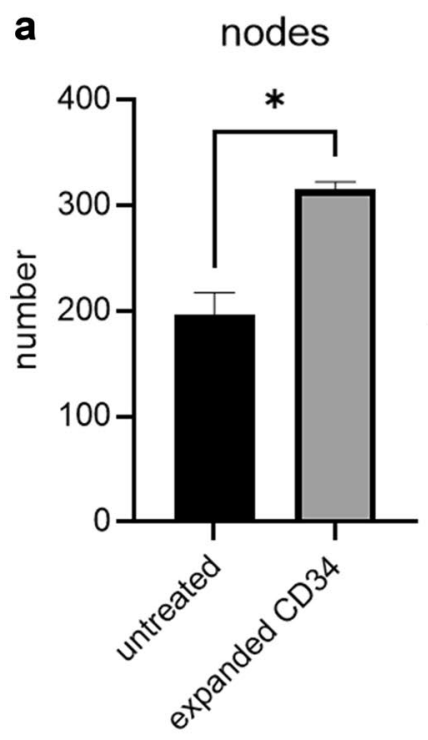

b junctions

c

meshes

d total branching length
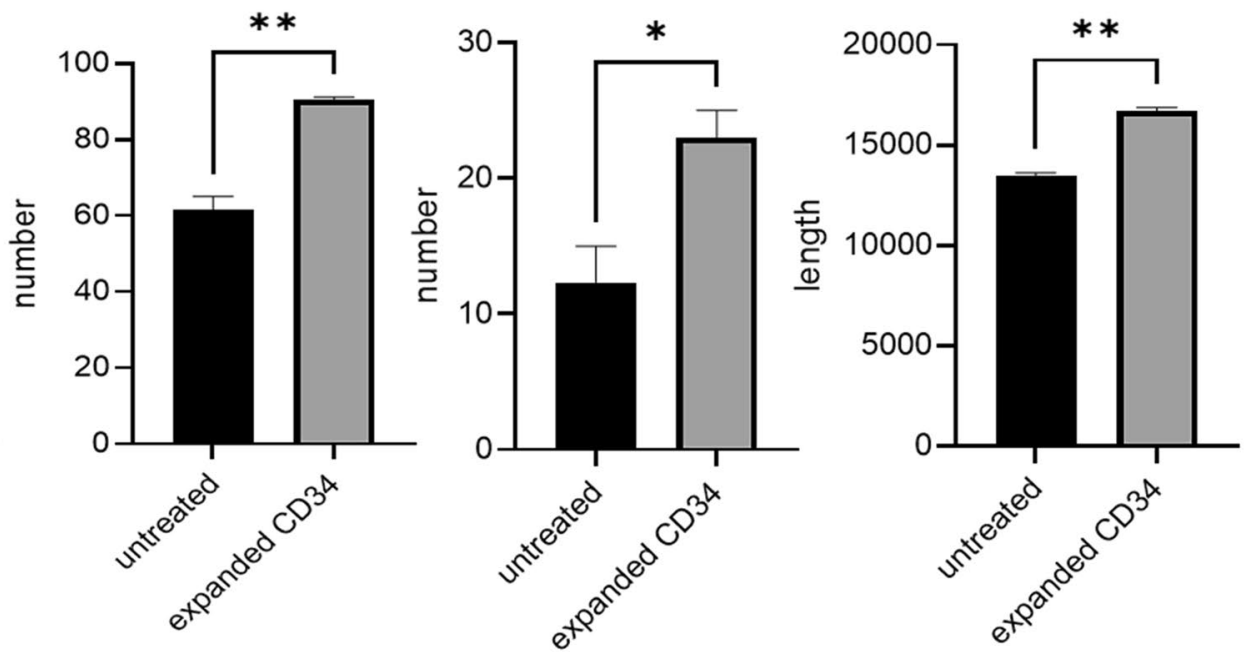

e
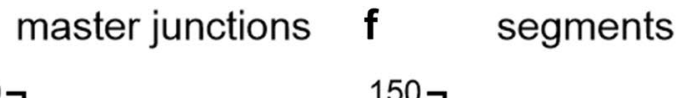

\section{g}
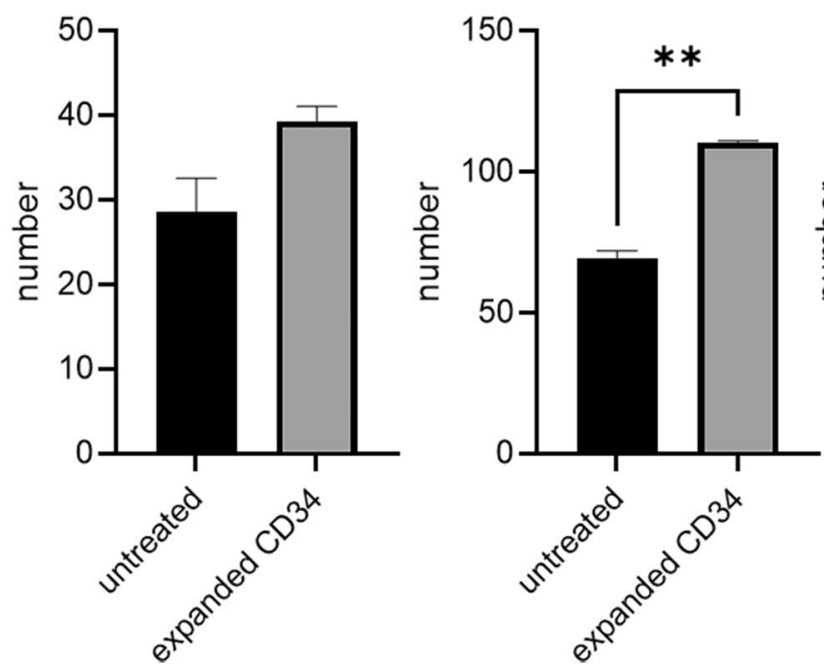

Fig. 4 Angiogenesis tube formation assay. 14-day UM171+SR-1 expanded CD34+ cells effect on HUVEC tube formation. Nodes (a), junctions (b), meshes (c), total branching length $(\mathbf{d})$, master junctions

\section{Effect of expanded CD34 + cells on cytokine response in LPS stimulated microglia}

Microglia were isolated by selection of $\mathrm{CD} 11 \mathrm{~b}+$ cells from the cortex of post-natal day 3 rat pups. When microglia were challenged with LPS, there was a significant up-regulation of proinflammatory genes; TNF $(\mathrm{p}<0.001)$ and IL-1 $\beta(\mathrm{p}<0.001)$ and of the anti-inflammatory IL-1RA $(\mathrm{p}<0.001)$ compared to the untreated control (Fig. 5c). When co-cultured with expanded CD34 + cells, there was no significant difference in microglial production of TNF and IL-1RA gene expression compared to microglia + LPS. However, co-culture of
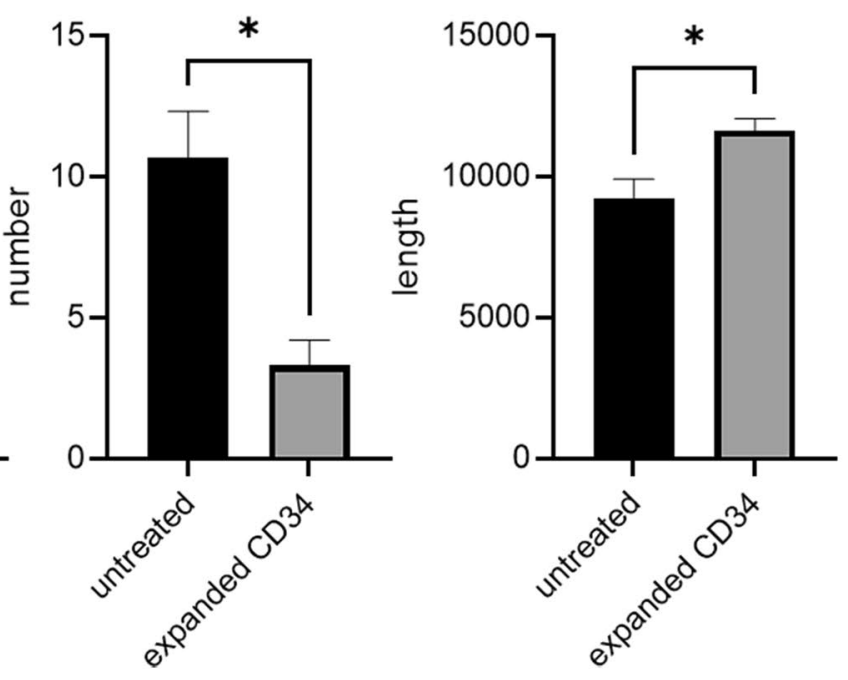

(e), segments (f), isolated segments (g) and total segment length (h). NT non-CD34 + cell treated. $* \mathrm{P}<0.05$ and $* * \mathrm{P}<0.01, \mathrm{~N}=3$ independent experiments

expanded CD34+cells was able to significantly downregulate expression of IL-1 $\beta(\mathrm{p}<0.001)$ compared to microglia + LPS.

\section{Discussion}

Umbilical cord blood is a rich source of HSCs; however, the number of HSCs obtained from single UCB units may not be sufficient for regenerative medicine applications, particularly if cells are to be given to an adult or multiple doses are required. Cell expansion addresses this limitation for the use of HSC cell-based therapies by generating sufficient 
Fig. 5 Glial cell proliferation and microglia anti-inflammatory assay. Effect of CD34 + cells on glial cell proliferation (a). TBHP induction of oxidative stress comparing untreated cells (NT) and the addition of TBHP with either pre- or post-expanded CD34+cells (b). Effect of CD34+cells to augment cytokine gene expression on microglia challenged with LPS $(\mathbf{c})$. $* \mathrm{P}<0.05, * * \mathrm{P}<0.01, * * * \mathrm{P}<0.001 . \mathrm{N}=3$ independent experiments

cell numbers, but up until now it has not been determined if ex vivo expansion of HSCs impacts the paracrine secretions and function of these cells. Accordingly, in the current study we addressed this knowledge gap by carrying out cell expansion of UCB CD34 + cells using various individual and combined doses of standard growth factors (TPO, SCF, IL-6 and FLT-3), LDL and the small molecules (UM171 and SR-1) over 7 or 14 days. Our results have shown that UCB CD34+cell expansion is achievable with greater than 1000-fold cell expansion of CD34/CD45 + cells at 14 days when both small molecules UM171 and SR-1 were added to the media. Expansion was significantly greater at 14 days compared to 7 days, within the order of $10 \times$ greater total cell numbers. Finally, we describe here for the first time that expansion of CD34+ cells with TPO, SCF, FLT3, IL-6, UM171 and SR-1 led to an up-regulation of the neurotrophic factors GDNF, BDNF, NTF-3 and NTF-4 as well as the angiogenic factors VEGF and ANG, but not of ANGPT1. In addition, we have shown, in vitro, that expanded CD34 + cells improve angiogenesis and glial proliferation and significantly reduce oxidative stress and microglial IL-1B expression.

Our results demonstrate that the addition of UM171 and SR-1 to SGF (TPO, IL-6, SCF and FLT-3) supported selfrenewal of CD34+-derived cells over a two-week expansion culture when compared to SGF or either UM171 or SR-1 added individually, which was most likely due to the fact that both molecules target different pathways (Boitano et al. 2010; Chagraoui et al. 2021). Previous expansion studies using TPO, FLT-3, IL-6, IL-3 and SCF (Petzer et al. 1996) resulted in poor expansion and differentiation of CD34+cells. Methods to try to address this issue have used co-cultures containing mesenchymal stromal cells to recapitulate the HSC niche (Jing et al. 2010; Kadekar et al. 2015) or addition of factors including notch ligands (Delaney et al. 2010), FGF (de Haan et al. 2003), pleiotrophin (Himburg et al. 2010), angiopoietinlike proteins (Zhang et al. 2006), valproic acid (De Felice et al. 2005), low density lipoproteins (LDL) (Cimato et al. 2013), GSK-3 $\beta$ inhibitors (Ko et al. 2011) and nicotinamide (Horwitz et al. 2014). More recently, increased attention has focused on the use of small molecules to regulate stem cell fate. Of interest with respect to regulation of HSC expansion are the small molecules SR-1, an aryl hydrocarbon receptor antagonist (Boitano et al. 2010) and UM171, a pyrimidoindole derivative (Fares et al. 2014). These small molecules have shown promising results in their ability for ex vivo a

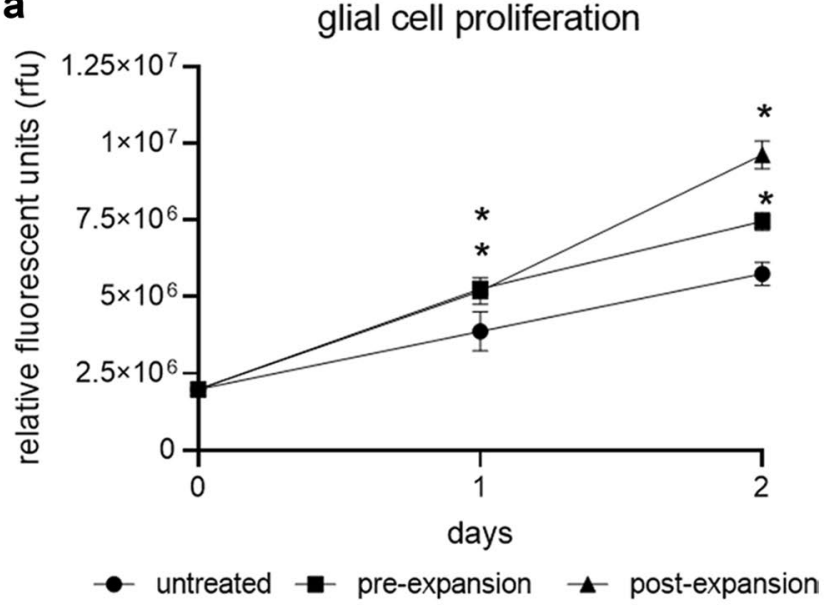

b ROS production

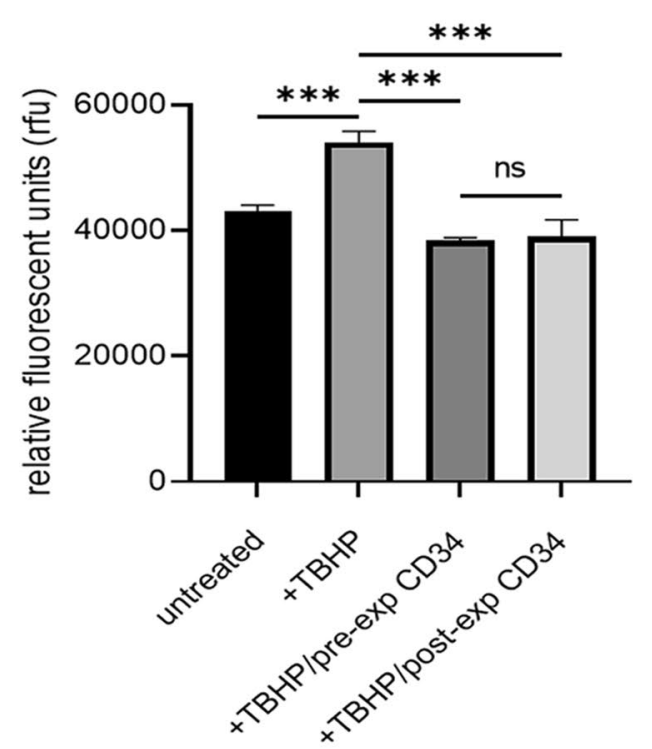

C microglia response to LPS

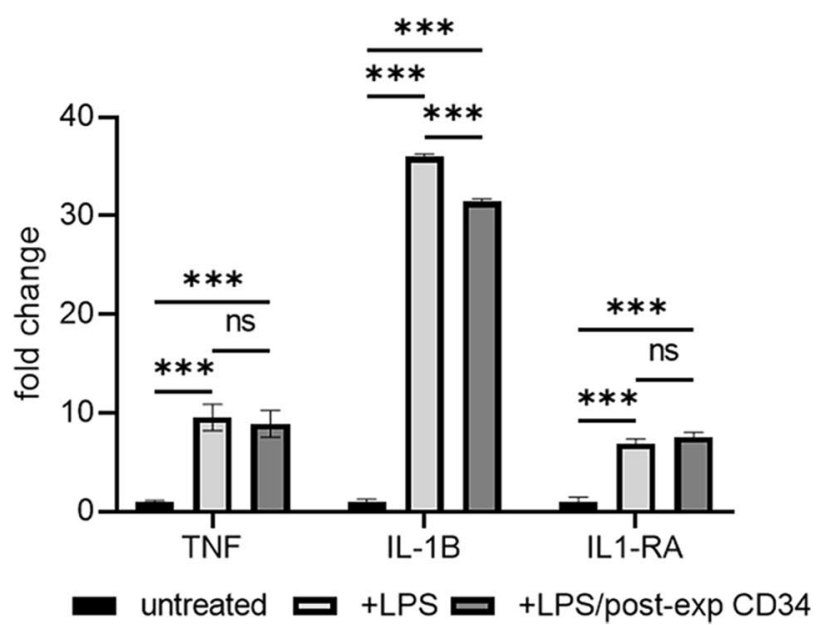


expansion of HSCs where the addition of SR-1 results in a 50-fold increase in HSCs (Boitano et al. 2010) and UM171 resulted in expansion of HSCs by up to 100-fold in 7 days of culture. These expanded cells also showed the ability for long-term repopulation in vivo either in combination with SR-1 or when added alone (Fares et al. 2014). The discovery of these small molecules has led to advances in the clinical use of small molecule expanded HSCs for use in haematological indications (Wagner et al. 2016; Cohen et al. 2020; Dumont-Lagacé et al. 2020).

In our CD34 + expansion culture system, we found that the optimal UM171 concentration of $150 \mathrm{nM}$ maintained CD34 + HSC self-renewal without negatively impacting proliferation and their secretome. The number of HSCs that can be generated during ex vivo expansion is a function of the cell fate such as quiescence, proliferation, differentiation, and death which, in turn, can be regulated ex vivo by extrinsic factors (Domen and Weissman 1999; Bonde et al. 2004; Ross and Li 2006). The expansion protocol described in this study used $1 \times 10^{4} \mathrm{CD} 34+$ cells as a starting point in a 24 well format and, by day 7, the cells reach approximately $80 \%$ confluence. These cells were split at a ratio of $1: 20$ and further cultured for an additional 7 days. This passaging at day 7 allowed the cells to continue to rapidly proliferate and resulted in a total expansion of CD34+CD45 + cells of 1120-fold at day 14, when SR-1 and UM171 were added to the media at a dose of $150 \mathrm{nM} .14$ day expansion using UM171 combined with SR-1 resulted in the loss of CFU-E colony-forming potential, which is consistent with the findings that UM171 alone can inhibit erythroid and megakaryocyte differentiation (Fares et al. 2014). However, the 14-day expansion with UM171 + Sr-1 resulted in the gain of CD34+CD45 + CD43 + CD90 + progenitors, whereas expansion without UM171 and SR-1 resulted in a lower yield of these progenitors. This population of progenitors has been suggested to be a more primitive HSC and is capable of long-term repopulating activity (Radtke et al. 2020) suggestive that the expansion set out in this study promotes expansion of a primitive phenotype of HSC.

CD34 + cells have been well characterised for their ability to promote angiogenesis by expression of angiogenic factors (Scheubel et al. 2010; Sahoo et al. 2011; Mathiyalagan et al. 2017). In in vivo animal models, treatment of hypoxic ischemic brain injury with CD34 + cells improved vascular regeneration and cerebral blood flow, as well as a reduction in apoptosis (Ohshima et al. 2016; Yu et al. 2019). The mechanisms of action of CD34 + cells for repair and regeneration is suggested to be due to paracrine action, rather than engraftment and differentiation of the cells at the site of injury. This paracrine effect stimulates proliferation of endogenous cells as well as regulation of cell survival through the secretion of growth and trophic factors such as neurotropic and angiogenic factors (Wang et al. 2013;
Zhao et al. 2014; Englander et al. 2015). In our studies using UM171/SR-1 expanded UCB CD34 + cells resulted in the significant upregulation of the angiogenic factors VEGF and ANG, but not ANGPT1, suggestive that 14-day expanded CD34 + cells are not negatively impacted in their ability to promote angiogenesis. To further assess this capacity, we used a tube formation assay using HUVECs co-cultured with the CD34+ cells. We showed that the addition of CD34 + cells promoted tube formation with increased numbers of segments, junctions and meshes, as well as increased length of the segments and junctions, while there was a significant decrease in the number of isolated segments (incomplete segments). This suggests that a 14-day expansion did not negatively affect CD34 angiogenic activity in vitro.

Neurotrophic factors are a family of proteins that regulate proliferation, differentiation, survival and apoptosis in cells of the nervous system (Hefti et al. 1993; Thorne and Frey 2001). Neurotrophic factors have been directly linked to preventing neuronal cell death in the injured brain (Kubo et al. 1995; Schäbitz et al. 2007; Fantacci et al. 2013; Chen et al. 2019). Studies have shown unmanipulated bone marrow-derived $\mathrm{CD} 34+$ cells express higher levels of the neurotrophic factors NGF, BDNF, GDNF, NTF-3 and NTF-4, as well as their receptors Trk-A, Trk-B, P75NTR when compared to bone marrow-derived nucleated cells (Paczkowska et al. 2016). However, the impact of expansion on trophic factor expression has not previously been assessed. Here, we describe for the first time that expansion of CD34 + cells with TPO, SCF, FLT-3, IL-6, UM171 and SR-1 led to an up-regulation of the neurotrophic factors GDNF, BDNF, NTF-3 and NTF-4. This up-regulation of neurotrophic factors could be due to the specific factors used to expand the CD34+ cells which may have promoted the up-regulation of the genes we assessed or, the upregulation could be caused by the change in phenotype of the CD34+cells as expansion does result in some maturing of CD34 + cells over time.

Our results demonstrated that expanded CD34 + cells upregulated neurotrophic factors which can have a role in regenerative processes, and we next assessed the impact of these cells on glial cells isolated from the brains of three-day old rat pups. Growth factors that are secreted by HSCs have been shown to regulate proliferation, differentiation, and release of blood cell lineages into the circulation (Majka et al. 2001; Paczkowska et al. 2016). These growth factors have also been shown to regulate the proliferation of neural stem/progenitor cells (Cattaneo and McKay 1990; Arsenijevic et al. 2001; Younsi et al. 2020). Results from our study found that both pre- and post-expanded CD34+cells significantly increased glial cell proliferation; however, the expanded CD34 + cells caused greater proliferation in the glial cells than the preexpanded cells, suggestive that the higher proliferation may be correlated to the up-regulation of neurotrophic factors after expansion. A number of studies using pre-clinical 
animal models have investigated the neuroprotective/neuroreparative potential of UCB cells for treating hypoxic ischemic brain injury in neonates and adult. These studies report that UCB cell administration has neuroprotective/neuroregenerative benefits with improvements in motor control and coordination, as well as reduced neuronal degeneration and apoptosis, and that UCB cells protect neuronal and glial cell populations in response to preterm and term brain injury (Ohshima et al. 2016; McDonald et al. 2018; Paton et al. 2018; Yu et al. 2019). It is possible that the CD34+ cells present in UCB provide a neuroprotective and functional role and that our expanded cord blood cells could have the potential to provide a therapeutic benefit in neuroprotective/ neuroreparative applications.

Cells of the myeloid lineage and resident microglia in the brain play a major role in the pathogenic processes that contribute to tissue damage in brain injury by promoting neuroinflammation and oxidative stress (Tichauer et al. 2007; Rosales-Corral et al. 2010; Pathipati et al. 2013; Bhalala et al. 2015). Here, we showed that when cultured microglia were stimulated with the inflammatory stimulator LPS, the inflammatory cytokines TNF, and IL- $1 \beta$ were up-regulated along with the anti-inflammatory IL-1RA. When microglia were co-cultured with expanded CD34 + cells, there was no difference in TNF or IL-1RA gene expression levels, but there was a significant down-regulation of the pro-inflammatory cytokine IL-1 $\beta$, suggesting that expanded CD34+ cells are also anti-inflammatory.

Finally, we showed that UCB expanded CD34+ cells could attenuate reactive oxygen species (ROS) production in rat glial cells that were treated with TBHP, an oxidative stress inducer (Roy and Sil 2012). When comparing pre- and post-expanded $\mathrm{CD} 34+$ cells, there was no difference in their ability to downregulate ROS, indicating that expansion of the cells does not negatively impact the anti-oxidant capacity of CD34 + cells. Oxidative stress caused by pathological changes can result in the over production and impaired clearance of ROS, a key mechanism contributing to tissue damage and functional deficits in hypoxic-ischemic brain injury (Ten and Starkov 2012; Vasiljević et al. 2012; Zhao et al. 2016). It is possible that the effect of CD34 + cells on oxidative stress in glial cells could also be due to providing anti-oxidant support to the glial cells, which remains to be confirmed in future experiments.

In summary, UCB-derived CD34 + HSCs, cultured using a 14-day expansion protocol, showed a robust expansion capacity that supports the therapeutic use of such cells. The 14-day expanded UCB-CD34 cells retain functionality when tested in in vitro assays where they promoted cell proliferation, attenuated ROS production caused from oxidative stress and promoted angiogenesis. Future studies will confirm the therapeutic potential of these cells in vivo and the scale up method for production of GMP compliant cells for therapeutic regenerative medicine clinical trials.
Funding Open Access funding enabled and organized by CAUL and its Member Institutions. This work was supported by the Victorian Government's Operational Infrastructure Support Program. AW is a recipient of a Science and Industry Endowment Fund STEM+ Business Postdoctoral Fellowship, jointly funded by Cell Care Australia. This work is also supported by a Monash Health Foundation research grant.

\section{Declarations}

Ethics approval All collections of UCB for experiments in this project were performed with human ethics approval from Monash Health Human Ethics Committee, Monash Medical Centre (HREC Ref. Research Project No.: 12387B). Animal ethics approval was obtained from Monash Medical Centre Animal Ethics Committee A (MMCA/2015/42). All experiments were performed in accordance with the Australian National Health and Medical Research Council guidelines.

Competing interests The authors declare that they have no competing interests.

Open Access This article is licensed under a Creative Commons Attribution 4.0 International License, which permits use, sharing, adaptation, distribution and reproduction in any medium or format, as long as you give appropriate credit to the original author(s) and the source, provide a link to the Creative Commons licence, and indicate if changes were made. The images or other third party material in this article are included in the article's Creative Commons licence, unless indicated otherwise in a credit line to the material. If material is not included in the article's Creative Commons licence and your intended use is not permitted by statutory regulation or exceeds the permitted use, you will need to obtain permission directly from the copyright holder. To view a copy of this licence, visit http://creativecommons.org/licenses/by/4.0/.

\section{References}

Aguila HL, Akashi K, Domen J, Gandy KL, Lagasse E, Mebius RE, Morrison SJ, Shizuru J, Strober S, Uchida N, Wright DE, Weissman IL (1997) From stem cells to lymphocytes: biology and transplantation. Immunol Rev 157:13-40

Arsenijevic Y, Weiss S, Schneider B, Aebischer P (2001) Insulin-like growth factor-I is necessary for neural stem cell proliferation and demonstrates distinct actions of epidermal growth factor and fibroblast growth factor-2. J Neurosci : Official J Soc Neurosci 21(18):7194-7202

Baraniak PR, McDevitt TC (2010) Stem cell paracrine actions and tissue regeneration. Regen Med 5(1):121-143

Bhalala US, Koehler RC, Kannan S (2015) Neuroinflammation and neuroimmune dysregulation after acute hypoxic-ischemic injury of developing brain. Front Pediatr 2:144-144

Boitano AE, Wang J, Romeo R, Bouchez LC, Parker AE, Sutton SE, Walker JR, Flaveny CA, Perdew GH, Denison MS, Schultz PG, Cooke MP (2010) Aryl hydrocarbon receptor antagonists promote the expansion of human hematopoietic stem cells. Science 329(5997):1345-1348

Boltze J, Kowalski I, Geiger K, Reich D, Gunther A, Buhrle C, Egger D, Kamprad M, Emmrich F (2005) "Experimental treatment of stroke in spontaneously hypertensive rats by CD34+ and CD34cord blood cells." German medical science : GMS e-journal 3: Doc09-Doc09.

Bonde J, Hess DA, Nolta JA (2004) Recent advances in hematopoietic stem cell biology. Curr Opin Hematol 11(6):392-398 
Bradstock KF, Hertzberg MS, Kerridge IH, Svennilson J, McGurgan M, Huang G, Antonenas V, Gottlieb DJ (2006) Unrelated umbilical cord blood transplantation for adults with haematological malignancies: results from a single Australian centre. Intern Med J 36(6):355-361

Cattaneo E, McKay R (1990) Proliferation and differentiation of neuronal stem cells regulated by nerve growth factor. Nature 347(6295):762-765

Chagraoui J, Girard S, Spinella J-F, Simon L, Bonneil E, Mayotte N, MacRae T, Coulombe-Huntington J, Bertomeu T, Moison C, Tomellini E, Thibault P, Tyers M, Marinier A, Sauvageau G (2021) UM171 Preserves Epigenetic Marks that Are Reduced in Ex Vivo Culture of Human HSCs via Potentiation of the CLR3KBTBD4 Complex. Cell Stem Cell 28(1):48-62.e6

Chen H, Dang Y, Liu X, Ren J, Wang H (2019) Exogenous brainderived neurotrophic factor attenuates neuronal apoptosis and neurological deficits after subarachnoid hemorrhage in rats. Exp Ther Med 18(5):3837-3844

Cimato TR, Palka BA, Lang JK, Young RF (2013) "LDL Cholesterol Modulates Human CD34+ HSPCs through Effects on Proliferation and the IL-17 G-CSF Axis." PLoS One 8(8): e73861.

Cohen S, Roy J, Lachance S, Delisle JS, Marinier A, Busque L, Roy DC, Barabé F, Ahmad I, Bambace N, Bernard L, Kiss T, Bouchard P, Caudrelier P, Landais S, Larochelle F, Chagraoui J, Lehnertz B, Corneau S, Tomellini E, van Kampen JJA, Cornelissen JJ, Dumont-Lagacé M, Tanguay M, Li Q, Lemieux S, Zandstra PW, Sauvageau G (2020) Hematopoietic stem cell transplantation using single UM171-expanded cord blood: a single-arm, phase 1-2 safety and feasibility study. Lancet Haematol 7(2):e134-e145

Czechowicz A, Weissman IL (2011) Purified hematopoietic stem cell transplantation: the next generation of blood and immune replacement. Hematol Oncol Clin North Am 25(1):75-87

De Felice L, Tatarelli C, Mascolo MG, Gregorj C, Agostini F, Fiorini R, Gelmetti V, Pascale S, Padula F, Petrucci MT, Arcese W, Nervi C (2005) Histone deacetylase inhibitor valproic acid enhances the cytokine-induced expansion of human hematopoietic stem cells. Cancer Res 65(4):1505-1513

de Haan G, Weersing E, Dontje B, van Os R, Bystrykh LV, Vellenga E, Miller G (2003) In vitro generation of long-term repopulating hematopoietic stem cells by fibroblast growth factor-1. Dev Cell 4(2):241-251

Delaney C, Heimfeld S, Brashem-Stein C, Voorhies H, Manger RL, Bernstein ID (2010) Notch-mediated expansion of human cord blood progenitor cells capable of rapid myeloid reconstitution. Nat Med 16(2):232-236

Domen J, Weissman IL (1999) Self-renewal, differentiation or death: regulation and manipulation of hematopoietic stem cell fate. Mol Med Today 5(5):201-208

Dumont-Lagacé M. Li Q, Tanguay M, Chagraoui J, Kientega T, Cardin GB, Brasey A, Trofimov A, Carli C, Ahmad I, Bambace NM, Bernard L, Kiss TL, Roy J, Roy DC, Lemieux S, Perreault C, Rodier F, Dufresne SF, Busque L, Lachance S, Sauvageau G, Cohen S, Delisle J-S (2020) "UM171-Expanded Cord Blood Transplants Support Robust T Cell Reconstitution with Low Rates of Severe Infections." Biol Blood Marrow Transplant

Englander ZA, Sun J, Laura C, Mikati MA, Kurtzberg J, Song AW (2015) Brain structural connectivity increases concurrent with functional improvement: evidence from diffusion tensor MRI in children with cerebral palsy during therapy. NeuroImage Clinical $7: 315-324$

Fantacci C, Capozzi D, Ferrara P, Chiaretti A (2013) Neuroprotective role of nerve growth factor in hypoxic-ischemic brain injury. Brain Sci 3(3):1013-1022

Fares I, Chagraoui J, Gareau Y, Gingras S, Ruel R, Mayotte N, Csaszar E, Knapp DJHF, Miller P, Ngom M, Imren S, Roy DC, Watts KL, Kiem HP, Herrington R, Iscove NN, Humphries RK, Eaves
CJ, Cohen S, Marinier A, Zandstra PW, Sauvageau G (2014) "Cord blood expansion. Pyrimidoindole derivatives are agonists of human hematopoietic stem cell self-renewal." Science (New York, N.Y.) 345(6203): 1509-1512

Felfly H, Muotri A, Yao H, Haddad GG (2010) Hematopoietic stem cell transplantation protects mice from lethal stroke. Exp Neurol 225(2):284-293

Flores-Guzmán P, Fernández-Sánchez V, Mayani H (2013) Concise review: ex vivo expansion of cord blood-derived hematopoietic stem and progenitor cells: basic principles, experimental approaches, and impact in regenerative medicine. Stem Cells Transl Med 2(11):830-838

Gervassi A, Lejarcegui N, Dross S, Jacobson A, Itaya G, Kidzeru E, Gantt S, Jaspan H, Horton H (2014) "Myeloid Derived Suppressor Cells Are Present at High Frequency in Neonates and Suppress In Vitro T Cell Responses." PLoS One 9(9): e107816.

Gluckman E, Broxmeyer HA, Auerbach AD, Friedman HS, Douglas GW, Devergie A, Esperou H, Thierry D, Socie G, Lehn P et al (1989) Hematopoietic reconstitution in a patient with Fanconi's anemia by means of umbilical-cord blood from an HLA-identical sibling. N Engl J Med 321(17):1174-1178

Hefti F, Denton TL, Knusel B, Lapchak PA (1993) 2 - Neurotrophic Factors: What Are They and What Are They Doing? Academic Press, Neurotrophic Factors. S. E. Loughlin and J. H. Fallon. San Diego, pp 25-49

Himburg HA, Muramoto GG, Daher P, Meadows SK, Russell JL, Doan P, Chi JT, Salter AB, Lento WE, Reya T, Chao NJ, Chute JP (2010) Pleiotrophin regulates the expansion and regeneration of hematopoietic stem cells. Nat Med 16(4):475-482

Horwitz ME, Chao NJ, Rizzieri DA, Long GD, Sullivan KM, Gasparetto C, Chute JP, Morris A, McDonald C, Waters-Pick B, Stiff P, Wease S, Peled A, Snyder D, Cohen EG, Shoham H, Landau E, Friend E, Peleg I, Aschengrau D, Yackoubov D, Kurtzberg J, Peled T (2014) Umbilical cord blood expansion with nicotinamide provides longterm multilineage engraftment. J Clin Invest 124(7):3121-3128

Hügle T, Daikeler T (2010) Stem cell transplantation for autoimmune diseases. Haematologica 95(2):185-188

Jing D, Fonseca A-V, Alakel N, Fierro FA, Muller K, Bornhauser M, Ehninger G, Corbeil D, Ordemann R (2010) Hematopoietic stem cells in co-culture with mesenchymal stromal cells-modeling the niche compartments in vitro. Haematologica 95(4):542-550

Kadekar D, Kale V, Limaye L (2015) Differential ability of MSCs isolated from placenta and cord as feeders for supporting ex vivo expansion of umbilical cord blood derived CD34+ cells. Stem Cell Res Ther 6(1):201

Kinniburgh D, Russell NH (1993) Comparative study of CD34-positive cells and subpopulations in human umbilical cord blood and bone marrow. Bone Marrow Transplant 12(5):489-494

Ko KH, Holmes T, Palladinetti P, Song E, Nordon R, O'Brien TA, Dolnikov A (2011) GSK-3 $\beta$ inhibition promotes engraftment of ex vivo-expanded hematopoietic stem cells and modulates gene expression. Stem Cells 29(1):108-118

Krause DS, Fackler MJ, Civin CI, May WS (1996) CD34: structure, biology, and clinical utility. Blood 87(1):1-13

Kubo T, Nonomura T, Enokido Y, Hatanaka H (1995) Brain-derived neurotrophic factor (bdnf) can prevent apoptosis of rat cerebellar granule neurons in culture. Dev Brain Res 85(2):249-258

Majka M, Janowska-Wieczorek A, Ratajczak J, Ehrenman K, Pietrzkowski Z, Kowalska MA, Gewirtz AM, Emerson SG, Ratajczak MZ (2001) Numerous growth factors, cytokines, and chemokines are secreted by human CD34+ cells, myeloblasts, erythroblasts, and megakaryoblasts and regulate normal hematopoiesis in an autocrine/paracrine manner. Blood 97(10):3075-3085

Mathiyalagan P, Liang Y, Kim D, Misener S, Thorne T, Kamide CE, Klyachko E, Losordo DW, Hajjar RJ, Sahoo S (2017) Angiogenic 
Mechanisms of Human CD34+ Stem Cell Exosomes in the Repair of Ischemic Hindlimb. Circ Res 120(9):1466-1476

McDonald CA, Penny TR, Paton MCB, Sutherland AE, Nekkanti L, Yawno T, Castillo-Melendez M, Fahey MC, Jones NM, Jenkin G, Miller SL (2018) Effects of umbilical cord blood cells, and subtypes, to reduce neuroinflammation following perinatal hypoxicischemic brain injury. J Neuroinflammation 15(1):47

Murohara T, Ikeda H, Duan J, Shintani S, Sasaki KI, Eguchi H, Onitsuka I, Matsui K, Imaizumi T (2000) Transplanted cord blood-derived endothelial precursor cells augment postnatal neovascularization $\mathrm{J}$ Clin Investig 1051115271536

Ohshima M, Taguchi A, Sato Y, Ogawa Y, Saito S, Yamahara K, Ihara M, Harada-Shiba M, Ikeda T, Matsuyama T, Tsuji M (2016) Evaluations of Intravenous Administration of CD34+ Human Umbilical Cord Blood Cells in a Mouse Model of Neonatal Hypoxic-Ischemic Encephalopathy. Dev Neurosci 38(5):331-341

Paczkowska E, Kaczyńska K, Pius-Sadowska E, Rogińska D, Kawa M, Ustianowski P, Safranow K, Celewicz Z, Machaliński B (2013) Humoral activity of cord blood-derived stem/progenitor cells: implications for stem cell-based adjuvant therapy of neurodegenerative disorders. PLoS ONE 8(12):e83833-e83833

Paczkowska E, Piecyk K, Luczkowska K, Kotowski M, Roginska D, Pius-Sadowska E, Oronowicz K, Ostrowski M, Machalinski B (2016) Expression of neurotrophins and their receptors in human CD34+ bone marrow cells. J Physiol Pharmacol 67(1):151-159

Park S-K, Won J-H (2009) Usefulness of umbilical cord blood cells in era of hematopoiesis research. International Journal of Stem Cells 2(2):90-96

Pathipati P, Müller S, Jiang X, Ferriero D (2013) Phenotype and Secretory Responses to Oxidative Stress in Microglia. Dev Neurosci 35(2-3):241-254

Paton MCB, Allison BJ, Li J, Fahey MC, Sutherland AE, Nitsos I, Bischof RJ, Dean JM, Moss TJM, Polglase GR, Jenkin G, McDonald CA, Miller SL (2018) Human Umbilical Cord Blood Therapy Protects Cerebral White Matter from Systemic LPS Exposure in Preterm Fetal Sheep. Dev Neurosci 40(3):258-270

Penny TR, Pham Y, Sutherland AE, Mihelakis JG, Lee J, Jenkin G, Fahey MC, Miller SL, McDonald CA (2020) "Multiple doses of umbilical cord blood cells improve long-term brain injury in the neonatal rat." Brain Res 1746: 147001

Petzer AL, Zandstra PW, Piret JM, Eaves CJ (1996) Differential cytokine effects on primitive (CD34+CD38-) human hematopoietic cells: novel responses to Flt3-ligand and thrombopoietin. $\mathbf{J}$ Exp Med 183(6):2551-2558

Phuc PV, Ngoc VB, Lam DH, Tam NT, Viet PQ, Ngoc PK (2012) Isolation of three important types of stem cells from the same samples of banked umbilical cord blood. Cell Tissue Bank 13(2):341-351

Qiu H, Qian T, Wu T, Wang X, Zhu C, Chen C, Wang L (2021) Umbilical cord blood cells for the treatment of preterm white matter injury: Potential effects and treatment options. J Neurosci Res 99(3):778-792

Radtke S, Pande D, Cui M, Perez AM, Chan YY, Enstrom M, Schmuck S, Berger A, Eunson T, Adair JE, Kiem HP (2020) Purification of Human CD34(+)CD90(+) HSCs Reduces Target Cell Population and Improves Lentiviral Transduction for Gene Therapy. Mol Ther Methods Clin Dev 18:679-691

Rocha V, Wagner JE Jr, Sobocinski KA, Klein JP, Zhang MJ, Horowitz MM, Gluckman E (2000) Graft-versus-host disease in children who have received a cord-blood or bone marrow transplant from an HLA-identical sibling. Eurocord and International Bone Marrow Transplant Registry Working Committee on Alternative Donor and Stem Cell Sources. N Engl J Med 342(25):1846-1854

Rosales-Corral S, Reiter RJ, Tan DX, Ortiz GG, Lopez-Armas G (2010) Functional aspects of redox control during neuroinflammation. Antioxid Redox Signal 13(2):193-247
Ross J, Li L (2006) Recent advances in understanding extrinsic control of hematopoietic stem cell fate. Curr Opin Hematol 13(4):237-242

Roura S, Pujal J-M, Gálvez-Montón C, Bayes-Genis A (2015) The role and potential of umbilical cord blood in an era of new therapies: a review. Stem Cell Res Ther 6(1):123

Roy A, Sil PC (2012) Tertiary butyl hydroperoxide induced oxidative damage in mice erythrocytes: Protection by taurine. Pathophysiology 19(2):137-148

Sahoo S, Klychko E, Thorne T, Misener S, Schultz KM, Millay M, Ito A, Liu T, Kamide C, Agrawal H, Perlman H, Qin G, Kishore R, Losordo DW (2011) Exosomes From Human CD34+ Stem Cells Mediate Their Proangiogenic Paracrine Activity. Circ Res 109(7):724-728

Schäbitz WR, Steigleder T, Cooper-Kuhn CM, Schwab S, Sommer C, Schneider A, Kuhn HG (2007) Intravenous brain-derived neurotrophic factor enhances poststroke sensorimotor recovery and stimulates neurogenesis. Stroke 38(7):2165-2172

Scheubel RJ, Holtz J, Friedrich I, Borgermann J, Kahrstedt S, Navarrete Santos A, Silber RE, Simm A (2010) Paracrine effects of CD34 progenitor cells on angiogenic endothelial sprouting. Int J Cardiol 139(2):134-141

Schwarting S, Litwak S, Hao W, Bähr M, Weise J, Neumann H (2008) Hematopoietic Stem Cells Reduce Postischemic Inflammation and Ameliorate Ischemic Brain Injury. Stroke 39(10):2867-2875

Sebrango A, Vicuña I, de Laiglesia A, Millán I, Bautista G, MartínDonaire T, Regidor C, Cabrera R, Fernandez MN (2010) Haematopoietic transplants combining a single unrelated cord blood unit and mobilized haematopoietic stem cells from an adult HLAmismatched third party donor:: Comparable results to transplants from HLA-identical related donors in adults with acute leukaemia and myelodysplastic syndromes. Best Pract Res Clin Haematol 23(2):259-274

Shenoy S (2013) Hematopoietic stem-cell transplantation for sickle cell disease: current evidence and opinions. Therapeutic Advances in Hematology 4(5):335-344

Shizuru JA, Negrin RS, Weissman IL (2005) Hematopoietic stem and progenitor cells: clinical and preclinical regeneration of the hematolymphoid system. Annu Rev Med 56:509-538

Shyu W-C, Lin S-Z, Chiang M-F, Su C-Y, Li H (2006) Intracerebral Peripheral Blood Stem Cell CD34+ Implantation Induces Neuroplasticity by Enhancing $\beta 1$ Integrin-Mediated Angiogenesis in Chronic Stroke Rats. J Neurosci 26(13):3444-3453

Sutherland DR, Keating A, Nayar R, Anania S, Stewart AK (1994) Sensitive detection and enumeration of CD34+ cells in peripheral and cord blood by flow cytometry. Exp Hematol 22(10):1003-1010

Swart JF, Delemarre EM, van Wijk F, Boelens J-J, Kuball J, van Laar JM, Wulffraat NM (2017) Haematopoietic stem cell transplantation for autoimmune diseases. Nat Rev Rheumatol 13(4):244-256

Taguchi A, Soma T, Tanaka H, Kanda T, Nishimura H, Yoshikawa $\mathrm{H}$, Tsukamoto Y, Iso H, Fujimori Y, Stern DM, Naritomi H, Matsuyama T (2004) Administration of CD34+ cells after stroke enhances neurogenesis via angiogenesis in a mouse model. J Clin Investig 114(3):330-338

Ten VS, Starkov A (2012) "Hypoxic-Ischemic Injury in the Developing Brain: The Role of Reactive Oxygen Species Originating in Mitochondria." Neurol Res Internatl 2012: 542976

Thompson LM, Ceja ME, Yang SP (2012) Stem cell transplantation for treatment of sickle cell disease: bone marrow versus cord blood transplants. Am J Health Syst Pharm 69(15):1295-1302

Thorne RG, Frey WH (2001) Delivery of Neurotrophic Factors to the Central Nervous System. Clin Pharmacokinet 40(12):907-946

Tichauer J, Saud K, von Bernhardi R (2007) Modulation by astrocytes of microglial cell-mediated neuroinflammation: effect on the activation of microglial signaling pathways. NeuroImmunoModulation 14(3-4):168-174 
Tiwari A, Wong CS, Nekkanti LP, Deane JA, McDonald C, Li J, Pham Y, Sutherland AE, Jenkin G, Kirkland MA (2018) "Controlling the Effective Oxygen Tension Experienced by Cells Using a Dynamic Culture Technique for Hematopoietic Ex Vivo Expansion." Current Proto Stem Cell Biol 44(1): 2A.11.1-2A.11.13

Tolar J, Hippen KL, Blazar BR (2009) Immune regulatory cells in umbilical cord blood: $\mathrm{T}$ regulatory cells and mesenchymal stromal cells. Br J Haematol 147(2):200-206

Tse W, Bunting KD, Laughlin MJ (2008) New insights into cord blood stem cell transplantation. Curr Opin Hematol 15(4):279-284

Van Epps DE, Bender J, Lee W, Schilling M, Smith A, Smith S, Unverzagt K, Law P, Burgess J (1994) Harvesting, characterization, and culture of CD34+ cells from human bone marrow, peripheral blood, and cord blood. Blood Cells 20(2-3):411-423

Vasiljević B, Maglajlić-Djukić S, Gojnić M, Stanković S (2012) The role of oxidative stress in perinatal hypoxic-ischemic brain injury. Srp Arh Celok Lek 140(1-2):35-41

Wagner JE Jr, Brunstein CG, Boitano AE, DeFor TE, McKenna D, Sumstad D, Blazar BR, Tolar J, Le C, Jones J, Cooke MP, Bleul CC (2016) Phase I/II Trial of StemRegenin-1 Expanded Umbilical Cord Blood Hematopoietic Stem Cells Supports Testing as a Stand-Alone Graft. Cell Stem Cell 18(1):144-155

Wang X-L, Zhao Y-S, Hu M-Y, Sun Y-Q, Chen Y-X, Bi X-H (2013) Umbilical cord blood cells regulate endogenous neural stem cell proliferation via hedgehog signaling in hypoxic ischemic neonatal rats. Brain Res 1518:26-35
Xie J, Zhang C (2015) Ex vivo expansion of hematopoietic stem cells. Sci China Life Sci 58(9):839-853

Younsi A, Zheng G, Scherer M, Riemann L, Zhang H, Tail M, Hatami M, Skutella T, Unterberg A, Zweckberger K (2020) Three Growth Factors Induce Proliferation and Differentiation of Neural Precursor Cells In Vitro and Support Cell-Transplantation after Spinal Cord Injury In Vivo. Stem Cells Internatl 2020:5674921

Yu Y, Yan Y, Luo Z, Luo P, Xiao N, Sun X, Cheng L (2019) Effects of human umbilical cord blood CD34+ cell transplantation in neonatal hypoxic-ischemia rat model. Brain Dev 41(2):173-181

Zhang CC, Kaba M, Ge G, Xie K, Tong W, Hug C, Lodish HF (2006) Angiopoietin-like proteins stimulate ex vivo expansion of hematopoietic stem cells. Nat Med 12(2):240-245

Zhang Y, Gao Y (2016) Novel chemical attempts at ex vivo hematopoietic stem cell expansion. Int J Hematol 103(5):519-529

Zhao F, Qu Y, Liu H, Du B, Mu D (2014) Umbilical cord blood mesenchymal stem cells co-modified by TERT and BDNF: A novel neuroprotective therapy for neonatal hypoxic-ischemic brain damage. Int J Dev Neurosci 38(1):147-154

Zhao M, Zhu P, Fujino M, Zhuang J, Guo H, Sheikh I, Zhao L, Li X-K (2016) Oxidative Stress in Hypoxic-Ischemic Encephalopathy: Molecular Mechanisms and Therapeutic Strategies. Int J Mol Sci 17(12):2078

Publisher's Note Springer Nature remains neutral with regard to jurisdictional claims in published maps and institutional affiliations. 